\title{
Monitoring groundwater chemical composition at an experimental area irrigated with petroleum produced water
}

Paula Stein ${ }^{1 *}$

Germano Melo Júnior ${ }^{2}$ Laécio Cunha de Souza ${ }^{2}$

${ }^{1}$ Academic Unit of Mining and Geology Federal University of Campina Grande Aprígio Veloso, 882

Campina Grande PB Brazil. CEP 58429-140

${ }^{2}$ Geology Department

Federal University of Rio Grande do Norte Natal RN Brazil.

CEP 59078-970

${ }^{*}$ Correspondent author

paula.stein@ufcg.edu.br

\section{RESUMO}

O reuso agrícola da água produzida é uma ação eficiente de gestão dos recursos hídricos. No entanto, é uma atividade potencialmente impactante ao solo e à água subterrânea, e dessa forma requer um monitoramento ambiental durante todo o processo. $\mathrm{O}$ presente trabalho tem como objetivo o monitoramento da qualidade da água de um aquífero cárstico, situado no nordeste do Brasil, frente a um experimento de irrigação utilizando água produzida no campo de petróleo de Fazenda Belém, no Estado do Ceará. Foram avaliados 12 poços de monitoramento, amostrados em quatro etapas: a primeira antes da instalação do experimento de irrigação (CHA) e as outras três, respectivamente, durante (MO1), imediatamente ao final (MO2) e após o experimento (MO3). O efeito climático também foi considerado na avaliação, uma vez que os eventos de amostragem ocorreram em períodos sazonais distintos: o primeiro e o último no final da estação seca e o segundo e terceiro no final da estação chuvosa. As investigações foram realizadas considerando dois grupos de poços: a montante e a jusante da área do experimento em relação ao fluxo das águas subterrâneas. Para $\mathrm{Ca}^{2+}, \mathrm{Mg}^{2+}, \mathrm{K}^{+}$, dureza total, $\mathrm{HCO}_{3}^{-}, \mathrm{F}^{-}$, As, $\mathrm{B}$, $\mathrm{Li}$ e $\mathrm{P}$, houve tendência de aumento das concentrações na amostragem de Monitoramento, em relação aos CHA. No entanto, esse cenário foi verificado em ambos os conjuntos de poços (montante e jusante) e, provavelmente relacionado a fatores naturais. As maiores concentrações ocorrem nas etapas de amostragem MO1 e MO2, ou seja, sob influência da estação úmida, quando a recarga de águas promove a dissolução dos constituintes carbonáticos presentes no aquífero, aumentando assim sua concentração dissolvida. As substâncias orgânicas analisadas não foram detectadas ou foram detectadas em concentrações muito baixas e dispersas e sem assinaturas específicas. A sua origem pode ser atribuída a fenômenos naturais ou difusos.

Palavras-chave: água produzida, monitoramento, aquífero cárstico, hidrogeoquímica.

\section{ABSTRACT}

Agricultural reuse of the produced water is an efficient means for water resource management. However it is a potentially impacting activity to soil and groundwater, and thus requires environmental monitoring throughout the process. From this perspective, the present work aims at the monitoring of groundwater quality of karstic aquifer, located in the northeast of Brazil, where an irrigation experiment was carried out using PW of the Fazenda Belém oil field, in Ceará State, Brazil. Twelve monitoring wells were evaluated through a four-stage sampling program: the first before the installation of the irrigation experiment (CHA) and the other three, respectively, during (MO1), immediately at the end (MO2) and after the experiment (MO3). The climatic effect was also considered in the evaluation, since sampling events occurred in distinct seasonal periods: the first and the last at the end of the dry season and the second and third at the end of the wet season. Investigations were performed considering two groups of wells: upstream wells and downstream wells in relation to groundwater flow in the experimental area. For $\mathrm{Ca}^{2+}, \mathrm{Mg}^{2+}$, $\mathrm{K}^{+}$, total hardness, $\mathrm{HCO}_{3}^{-}, \mathrm{F}^{-}, \mathrm{As}, \mathrm{B}, \mathrm{Li}$ and $\mathrm{P}$, there was a tendency of 
increasing concentrations in the Monitoring sampling, in relation to CHA. However, since this scenario was verified in both sets of wells (upstream and downstream), its causes are probably related to natural factors. It was also observed that highest concentrations occur predominantly in the MO1 and MO2 sampling stages, that is, under the influence of the wet season, when water recharges promote dissolution of carbonate constituents present in the aquifer, thus increasing its dissolved concentration. Organic substances analyzed in groundwater were not detected or were detected at very low and dispersed concentrations and without any source specific signatures. Hence, their origin can be attributed to natural or diffuse inputs.

Keywords: produce water, monitoring, karstic aquifer, hydrogeochemistry.

\section{INTRODUCTION}

Produce water $(\mathrm{PW})$ is a byproduct of petroleum activities, being the main effluent generated during oil and gas production. Brazil produces approximately 11 million oil barrels per day of PW and this number tends to increase due to the maturity of oil reservoirs (Fakhru'l-Razi et al., 2009). PW composition can change considerably, taking into consideration the hydrocarbon mixture, dissolved gases (including $\mathrm{CO}_{2}$ e $\mathrm{H}_{2} \mathrm{~S}$ ), dissolved solids (resulting in high salinity) and particulate matter (i.e. sand and silt) (Motta et al. 2013; Igunnu and Chen 2012). Frequently fluids (water and/or vapour) and additives are injected back into the rock formation during oil production and exploration activities, therefore PW chemical composition will be affected by these injected components (Veil et al. 2004).

Reuse of this water for agriculture irrigation is increasing with time, especially in dry areas, where water shortage is a known problem (Travis et al. 2012; Bixio et al. 2008; Johnston et al. 2008; Miller 2006; ALL 2003). Handling this effluent often requires implementation of specific techniques for water treatment, i.e. reverse osmose, before it become suitable for agriculture irrigation (Amini et al. 2012;

\section{DESCRIPTION OF STUDY AREA}

\subsection{IRRIGATION EXPERIMENT}

The study area is located at Aracati county, Ceará state, northeast of Brazil (Figure 1). Planting of ornamental species (i.e. pineapple and sunflower) and oil producer plants (sunflower and castor) was done in an area with dimensions of $120 \mathrm{~m} \times 160 \mathrm{~m}$, as showed in Figure 1. Plants were cultivated under three irrigation conditions, applying dripping irrigation process: 1 - Using PW submitted to
Stewart and Arnold 2011; Melo et al. 2010; Murray-Gulde et al. 2003). Reuse of treated PW for agricultural irrigation is a positive fate for this effluent, but it can still cause impact in the soil and shallow groundwater quality (Cutz-Pool at al. 2007; Allen and Robinson 1993). Ferreira et al. 2015 and Lopes et al. 2014 found changes in the mesofauna and in the microbiology composition of soils irrigated with PW.

This work presents the results of monitoring activities for groundwater quality in an area located in northeast part of Brazil. Monitoring was carried out during irrigation activities using PW from the Fazenda Belém oil field, at Ceará state. The main purposes of this study are: 1 - Describe the methodology used for monitoring groundwater quality, which can eventually be applied in similar situations. 2 - Define the hydrogeological model for the studied area and the main processes that control the original groundwater composition. 3 - Discuss hydrochemical groundwater composition and variation before, during and after PW irrigation activities, aiming to assess its impact in groundwaters.

a first phase treatment, consisting of oil and grease extraction and filtering of particulate matter. 2 - Using PW submitted to a second phase of treatment, encompassing oil and grease extraction, filtering and demineralization applying reverse osmosis treatment. 3 - Using water from Açu aquifer. In addition to three conditions, a fourth 
condition consisted of exposition of the plantation exclusively to the rain.

Table 1 shows chemical composition of the waters used in this work. The organic components BTEX (benzene, toluene, ethylbenzene, xylenes) and polycyclic hydrocarbons (HPAs) show concentration

\subsection{CLIMATE}

Climate of the region is classified as semiarid to semi-humid, with an annual average precipitation of $700 \mathrm{~mm}$ (period 1974 -2014)) (FUNCEME 2015). Rain season occurs between January and May and dry season

\subsection{GEOLOGY}

The studied area is located on the western portion of Potiguar Basin, which encompasses parts of Rio Grande do Norte and Ceará states. This basin is considered an important equatorial Brazilian Basin, genetically associated with crustal fragmentation and drifting, which resulted in the formation of the Atlantic Ocean from Lower Cretaceous age (Matos 1999). The Potiguar Basin comprises approximately $48,000 \mathrm{~km}^{2}$, being $45 \%$ of the area emerged and 55\% submerged (Araripe and Feijó 1994). The structural framework of the Basin is composed by three main units: levels below quantification limits. Fertilizing method consisted of application of organic fertilizer $\mathrm{CH}_{4} \mathrm{~N}_{2} \mathrm{O}$ (urea) and of $\mathrm{P}_{2} \mathrm{O}_{5}$ and $\mathrm{K}_{2} \mathrm{O}$. Plantation and harvest occurred between July 2012 and February 2014. After this period the studied area has been kept unaltered.

occurs between June and December, when the precipitation levels are bellow $30 \mathrm{~mm}$. Average temperature is approximately $28.3^{\circ} \mathrm{C}$, varying from $21.4^{\circ} \mathrm{C}$ to $34.9^{\circ} \mathrm{C}$.

grabens, horsts and basement platforms, all covered by sedimentary layers (Bertani et al. 1990). The stratigraphy of the Basin records a rifting stage followed by post-rifting and drift stages (Pessoa Neto et al. 2007). In this study, only the last stage is intercepted and is represented by the transgressive fluvial and marine sequences of Açu (sandstone) and Jandaira (limestone) Formations. Besides these stratigraphic units, there are continental sedimentary deposits of Neogene period, represented by Barreiras and Potengi Formations (Bezerra et al. 2006).

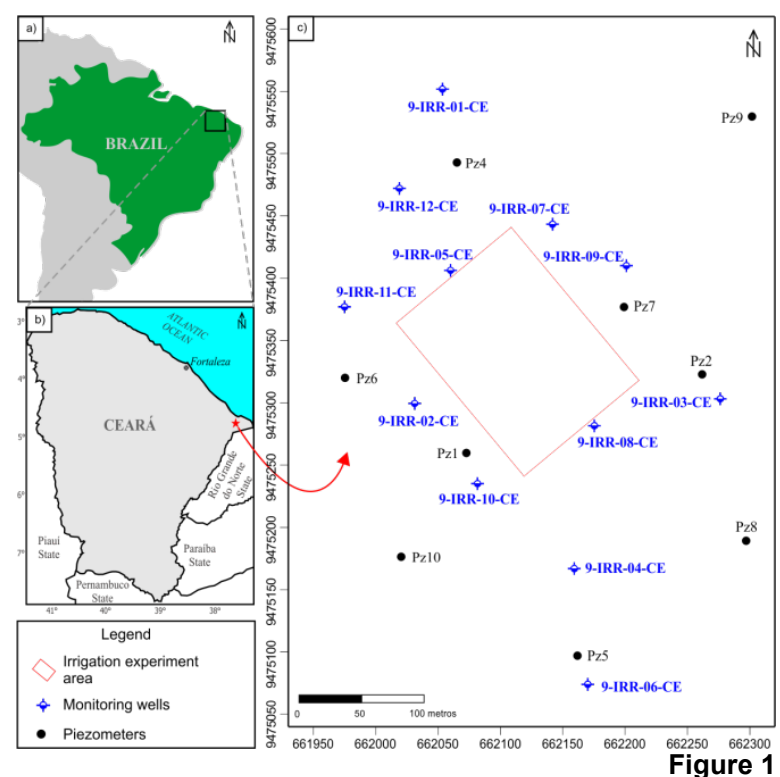

(a) Location of the Ceará State in the northeast of Brazil; (b) Location of the study area in the Ceará State; (c) Irrigation experiment area (rectangle) and drillings localization. 
Table 1 - Average chemical composition of water used for irrigation (Crisostomo et al. 2016)

\begin{tabular}{|c|c|c|c|c|}
\hline Parameter & Unit & $\begin{array}{l}\text { Groundwater } \\
\text { (Açu aquifer) }\end{array}$ & $\begin{array}{c}\text { PW } \\
\text { (filtrated) }\end{array}$ & $\begin{array}{c}\text { PW (reverse } \\
\text { osmosis) }\end{array}$ \\
\hline $\mathrm{pH}$ & - & 8.11 & 8.46 & 7.56 \\
\hline $\mathrm{EC}$ & $\mu \mathrm{S} / \mathrm{cm}$ & 690 & 267 & 530 \\
\hline $\mathrm{Ca}^{2+}$ & $\mathrm{mg} / \mathrm{L}$ & 8.8 & 6.4 & 4 \\
\hline $\mathrm{Mg}^{2+}$ & $\mathrm{mg} / \mathrm{L}$ & 2.9 & 25 & 7.1 \\
\hline $\mathrm{K}^{+}$ & $\mathrm{mg} / \mathrm{L}$ & 6.6 & 27.4 & 15.6 \\
\hline $\mathrm{Na}^{+}$ & $\mathrm{mg} / \mathrm{L}$ & 237.2 & 424.8 & 104.4 \\
\hline $\mathrm{HCO}_{3}^{-}$ & $\mathrm{mg} / \mathrm{L}$ & 171.9 & 214.1 & 87.8 \\
\hline $\mathrm{Cl}^{-}$ & $\mathrm{mg} / \mathrm{L}$ & 116.6 & 628.2 & 85.8 \\
\hline $\mathrm{Cu}$ & $\mathrm{mg} / \mathrm{L}$ & 0.001 & 0.001 & 0.001 \\
\hline $\mathrm{Fe}$ & $\mathrm{mg} / \mathrm{L}$ & 0.065 & 0.064 & 0.381 \\
\hline $\mathrm{Mn}$ & $\mathrm{mg} / \mathrm{L}$ & 0.004 & 0.002 & 0.007 \\
\hline $\mathrm{Zn}$ & $\mathrm{mg} / \mathrm{L}$ & 0.004 & 0.008 & 0.031 \\
\hline $\mathrm{Ag}$ & $\mu \mathrm{g} / \mathrm{L}$ & $<0.7$ & $<0.7$ & $<0.7$ \\
\hline As & $\mu \mathrm{g} / \mathrm{L}$ & 0.7 & 2.1 & $<0.4$ \\
\hline $\mathrm{Ba}$ & $\mu \mathrm{g} / \mathrm{L}$ & 110.3 & 155.4 & 25.2 \\
\hline B & $\mu \mathrm{g} / \mathrm{L}$ & 160.9 & 384.1 & 284.5 \\
\hline $\mathrm{Cd}$ & $\mu \mathrm{g} / \mathrm{L}$ & 0.5 & $<0.8$ & 0.3 \\
\hline $\mathrm{Co}$ & $\mu \mathrm{g} / \mathrm{L}$ & $<1.2$ & $<1.2$ & $<1.2$ \\
\hline $\mathrm{Cr}$ & $\mu \mathrm{g} / \mathrm{L}$ & 0.7 & 3.6 & 0.5 \\
\hline $\mathrm{Hg}$ & $\mu \mathrm{g} / \mathrm{L}$ & 0.2 & 0.2 & 0.4 \\
\hline $\mathrm{Ni}$ & $\mu \mathrm{g} / \mathrm{L}$ & 1.9 & 5.7 & 1.9 \\
\hline $\mathrm{Pb}$ & $\mu \mathrm{g} / \mathrm{L}$ & 4.9 & 5.7 & 6 \\
\hline $\mathrm{Zn}$ & $\mu \mathrm{g} / \mathrm{L}$ & 2.9 & 6.6 & 31.5 \\
\hline
\end{tabular}

EC: Electrical conductivity

\subsection{HYDROGEOLOGY}

The aquifer unit which has the best potential in the Potiguar Basin is the Açu Aquifer, inserted in the Açu Formation. This formation is composed by conglomerates on the bottom and a gradual grain decrease variation towards the top, represented by medium size sandstones in the medium layers and fine sandstones in the top, increasing clay content from bottom to top. (Angelim et al. 2006). In the south edge of the Basin a free groundwater system is observed, with wells reaching between 25 and $150 \mathrm{~m}$ depth and flow rates that reach $100 \mathrm{~m}^{3} / \mathrm{h}$ (Stein and Melo 2006; Morais et al. 2005). In the major confined area, the confinement is due to the occurrence of limestone rocks of Jandaira Formation on top, as equally registered in the studied area. This groundwater setting represents the most important hydrological system of the Basin, with capitation depths between 400 and $900 \mathrm{~m}$ and production flow rates that can reach values of $300 \mathrm{~m}^{3} / \mathrm{h}$ (Serhid 1998a). Chemical quality of its waters is generally good and can be used for all purposes (SRH 2005; Serhid 1998b).

Second to the Açu Aquifer, the Jandaíra karstic aquifer is a free system, inserted in limestones (grainstone and bioclastic mudstone) of the Jandaíra Formation. The carbonatic sequence can reach $600 \mathrm{~m}$ of depth, although the most important hydrogeological area is located between 50 and $150 \mathrm{~m}$, producing flow rates between 10 e $50 \mathrm{~m}^{3} / \mathrm{h}$ (Mistreta 1984). The top of Açu Formation represents the basement of Jandaira aquifer. Both units have isolated hydraulic systems and have distinct chemical composition in their waters (Carvalho Júnior et al. 2008). In some sectors of the basin, the Jandaíra aquifer develops a high level of karsification, playing a role of excellent hydraulic conductor and consequent high hydraulic potential (ANA 2010). This water is used mainly for irrigated agriculture, since salinity and water hardness in some sectors make it impossible its use for human consumption (Stein et al 2014; Melo et al 2007).

At the extreme North sector of the Potiguar Basin, overlying the Jandaíra aquifer, siliciclastic rocks and sediments are presented, representing Barreiras and Potengi Formations (Pessoa Neto et al. 2007), with low hydrogeological potential. These waters have high salinity, which restricts their use for various purposes, with wells up to 60 meters deep and maximum flow rate of $5 \mathrm{~m}^{3} / \mathrm{h}$ (SRH 2005; SERHID 1998a). Specifically in the study area, these siliciclastic sediments appear 
as a soft nonconsolidated cover, which does not constitute an aquifer because of its predominantly unsaturated condition (Xavier 2006).

\section{MATERIALS AND METHODS}

\subsection{HYDROGEOLOGY}

The development of conceptual models in karstic terrains is a task with many uncertainties and the definition of the preferred direction of underground flow should rely on a considerable number of piezometers (Kresic and Mikszewsky 2013, Goldscheider and Drew 2007). Taking these aspects into consideration, the hydrogeological survey in the present study consisted of the information obtained from nine piezometers and 12 monitoring wells, dug out within the scope of the present research and located in the surroundings of the studied area, covering an area of approximately 10 hectares (Figure 1).

Drilling, construction, cleaning and development of the monitoring wells were

carried out according to ABNT (2007). With the data obtained from the drilling (piezometers and monitoring wells) and the monthly measurement of the well's water level using water level meter, it was possible (1) to establish the conceptual hydrogeological model of the area, (2) to define and calibrate the piezometric surface (groundwater flow map) in the study area, and (3) to identify upstream and downstream wells of the experimental area, in relation to the underground flow of the Jandaíra aquifer. Groundwater flow mapping was achieved using Golden Surfer 9 software, with kriging being used as the data interpolation method.

\subsection{GROUNDWATER QUALITY}

\subsubsection{SAMPLING AND ANALYTICAL PROCEDURES}

Data acquisition resulted from four sampling stages, where water samples were collected from the 12 monitoring wells. The first sampling event occurred before the installation of the irrigation experiment, called Characterization (CHA), the second during the experiment, the third immediately at the end of its completion and the forth after the end of the experiment. The last three stages are here referred to as Monitoring 1 (MO1), Monitoring 2 (MO2) and Monitoring 3 (MO3). Table 2 presents information regarding the four sampling stages and the seasonal periods in which these stages took place.

Table 2 - Sampling information regarding the four stages of sample collection

\begin{tabular}{lclc}
\multicolumn{1}{c}{ Sampling } & Date & Period & $\begin{array}{c}\text { Total samples (with } \\
\text { duplicates) }\end{array}$ \\
\hline CHA - before the installation of the experiment & $11 / 06 / 2010$ to $11 / 12 / 2010$ & End of dry season & 19 \\
MO1 - during the experiment & $01 / 29 / 2013$ to $02 / 01 / 2013$ & During wet season & 22 \\
MO2 - immediately the end of the experiment & $02 / 12 / 2014$ to $02 / 15 / 2014$ & During wet season & 22 \\
MO3 - after the end of the experiment & $11 / 22 / 2014$ to $11 / 25 / 2014$ & End of dry season & 22 \\
\hline
\end{tabular}

Groundwater sampling was undertaken by the low flow method, as established by ABNT (2010). During water pumping, pH, Eh, electrical conductivity (EC), total dissolved solids (TDS), temperature (T) and dissolved oxygen (DO) were measured using a multiparameter flow cell (MP20, QED Environmental Systems) was used. Turbidity was also measured using a Hach portable digital turbidimeter. Of these parameters, only $\mathrm{pH}, \mathrm{EC}$ and TDS were used to evaluate the impact of the irrigation activity on groundwater. The others were measured in order to stabilize groundwater chemical conditions before sampling, according to ABNT (2010). Field handling, preservation and storage procedures for the samples followed recommendations of APHA (2005). Immediately after collection, the flasks containing sampled water were packed in iceboxes $\left(<4^{\circ} \mathrm{C}\right)$ and sent to the laboratory for determination within the recommended time limit for each analytical parameter

The major most common elements $\mathrm{Ca}^{2+}$, $\mathrm{Na}^{+}, \mathrm{Mg}^{2+}$ and $\mathrm{K}^{+}$and other 26 chemical elements ( $\mathrm{Ag}, \mathrm{Al}, \mathrm{As}, \mathrm{B}, \mathrm{Ba}, \mathrm{Be}, \mathrm{Cd}, \mathrm{Co}, \mathrm{Cr}$, $\mathrm{Cu}, \mathrm{Fe}, \mathrm{Hg}, \mathrm{Li}, \mathrm{Mn}$, , P, Pb, Sb, Se, Si, Tl, U, $\mathrm{V}, \mathrm{Zn}$ and $\mathrm{Zr}$ ) were analyzed. For the analysis 
of these 30 elements, field-filtered aliquots were obtained, using a disposable filter composed of polyethersulfone membrane with $0.45 \mu \mathrm{m}$ of porosity. Immediately after filling the flasks these aliquots were acidified with ultrapure $\mathrm{HNO}_{3}$ to $\mathrm{pH}<2$. The elements were determined by inductively coupled plasma mass spectrometry (ICP-MS) and by graphite furnace atomic absorption spectrometry (GF AAS). Total hardness was calculated according to APHA (2005). Analyses of $\mathrm{Cl}^{-}$,

\subsubsection{DATA ANALYSES}

Evaluation of the analytical data quality was done by ion balance calculation. Error margins were considered acceptable if below $10 \%$. Treatment of the analytical results was carried out using the software AquaChem v.5.1, which allowed characterization of water facies through diagram representations. The majority of the trace chemical elements had more than $25 \%$ of their results below the

\subsubsection{STATISTICAL PROCEDURES}

Hydrochemical variations in groundwater before (CHA) during (MO1 and MO2) and after (MO3) the irrigation experiment were based on the statistical evaluation considering two groups: (1) upstream wells and (2) 7 downstream wells in relation to the groundwater flow as established in the hydrogeological characterization. Non parametric statistics using the Friedman test (Hollander and Wolfe 1999) were applied to
$\mathrm{SO}_{4}{ }^{2-}, \mathrm{F}$ and $\mathrm{NO}_{3}^{-}$were performed by ion chromatography, whereas $\mathrm{HCO}_{3}^{-}$was determined by potentiometric titration. Volatile hydrocarbons (BTEX) were determined by gas chromatography combined with mass spectrometry (GCMS). Semi-volatile organic compounds (n-alkanes, isoprenoids, polycyclic aromatic hydrocarbons, alkylated and non alkylated dibenzothiophene, total petroleum hydrocarbons and phenols) were determined by gas chromatography with flow injection.

quantification limit (QL) of the method. These elements were excluded from further interpretation. For those elements with less than $25 \%$ of their results below QL (As, B, Ba, $\mathrm{Fe}, \mathrm{Li}$ and $\mathrm{P}$ ), these were considered in the interpretation procedures after replacing their below QL results by half of the QL (Keith et al., 1983).

observe if, within each of the above two groups, there is one or more sampling stages where the results, for a given analytical parameter, differ statistically from the other stages. This procedure was performed using the IBM SPSS Statistics 21 software. Also, descriptive statistics were calculated and represented in box plots. Scatter plots were applied to compare CHA data with MO1, MO2 e MO2 data.

\section{RESULTS AND DISCUSSIONS}

\subsection{HYDROGEOLOGY}

\subsubsection{HYDROGEOLOGICAL CONCEPTUAL MODEL}

The conceptual hydrogeological model established for the area (Figure 2), based on the data obtained in the wells (Table 3), shows that the surface area of the terrain is composed of a package of non-consolidated siliciclastic sediments (fine to medium quartz reddish sands) with an average thickness of about 14 meters (ranging from 9 to 28 meters). This variation is linked to the irregular paleo-relief of the upper surface of the Jandaíra limestone, which was developed due to dissolution by decarbonation and enhanced by the structural component. Regionally, this sedimentary cover is correlated to the Barreiras Formation (Cavalcante et al. 2003). Accurate studies in the Potiguar Basin show that, commonly, quaternary sedimentary deposits are mapped as such formation (Moura-Lima et al. 2010). In the present study, this formation is identified as "siliciclastic sediments" ( $i$, in Figure 2). These sediments do not develop saturated thicknesses, and thus act solely as a rainwater transfer unit (recharge) for storage in the karst conduits / channels / cavities of the Jandaíra Formation below.

The Jandaíra carbonate rocks presents an average thickness of 66.75 meters (ranging from 53 to 72 meters), where it was possible to individualize two units (ii and iii, in Figure 2). The upper portion is pure, whitish-coloured 
limestones with unsaturated fractures (ii, in Figure 2). This upper portion grades downward to limestone with sand and/or clay, creamcolored intercalations with saturated fractions and finer grayish-green facies (calcilutites) at the base (iii, in Figure 2). Water levels adjusted to an average depth of 63.21 meters (ranging from 58.76 to 66.62 meters on 08/21/2010), showing small saturated thicknesses, considering that the base of the carbonate package is approximately 81 meters. In fact, Diniz et al (2015) indicates the low hydrogeological potential of this formation in the area. In any case, this is considered the main shallow aquifer of the region and therefore the first to be affected by the potential effects of the irrigation experiment,

thus justifying the monitoring of the waters of the Jandaíra aquifer in the scope of this study.

The top of the Açu Formation starts, on average, at 81 meters depth, composed of reddish brown shales (iv, in Figure 2) in its upper portion. The Açu aquifer is the main aquifer in the confined area of study, providing flow rates of $100 \mathrm{~m}^{3} / \mathrm{h}$. Its productivity can supply water to cities and large irrigation projects, through deep wells of the order of 200 meters (Diniz et al, 2015). Considering the objectives of the work, this aquifer is not monitored in the present study due to its confined character and the high depth of capture. Carvalho Júnior et al (2008) reiterates that this aquifer is hydraulically isolated and has distinct hydrochemical signature from the Jandaíra aquifer in the studied sector.

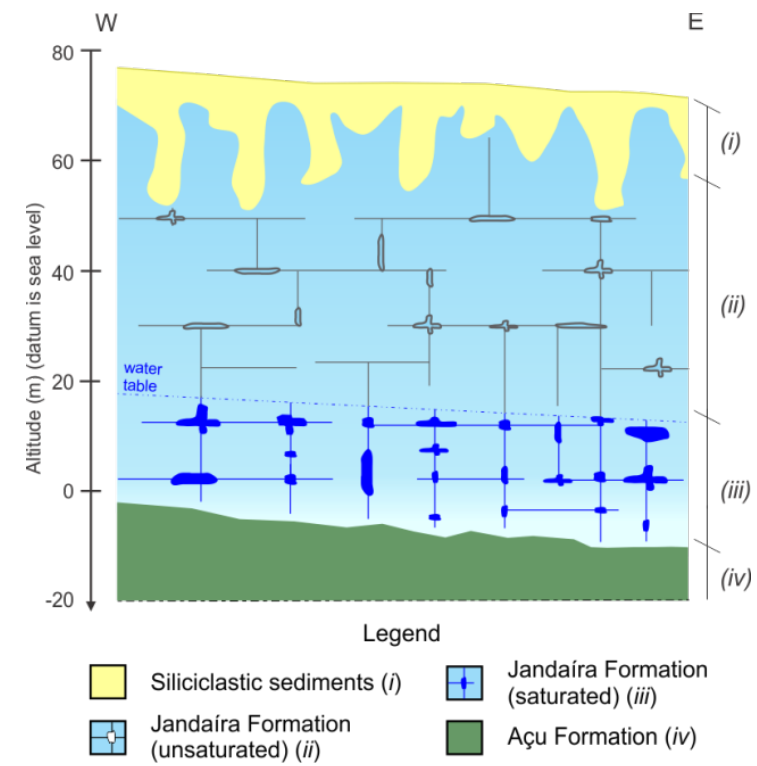

Figure 2

Generalized geological and hydrogeological conceptual model for the study area: (i) siliciclastic sediments; (ii to iii) Jandaíra Formation - limestones; (iv) Açu Formation - sandstones and shales (hydrogeological basement).

Terrain topography of the area elevates from west to east (Figure 3A), as also does the depth of the hydrogeological basement (Açu Formation), which is shallower in the western portion and deeper in the eastern range (Figure 3C). Depth of the water level in the wells follows the same upward trend from west to east (Figure 3B). This scenario corroborates the free nature of the Jandaíra aquifer.

\subsubsection{GROUNDWATER LEVELS}

Figure 4 shows an oscillation in the water level of wells at 0.50 meters during the monitored period, the deepest quota in March and the shallower in December. Maximum rainfall occurred in April and from June there is a slight recovery of levels that extends until
Recharge waters, when infiltrating the surface of the terrain (siliciclastic sediments of high permeability), percolate down to the conduits and karstic cavities of the Jandaíra carbonate. The flow stops its vertical migration by intercepting the impermeable surface of the Açu Formation. From there, waters flow horizontally following the upper pattern of the top of the Açu Formation (Figure 2).
November. From there it reacts abruptly in December, remaining shallow until February, in comparison to the other months. Thus, sampling events in January and February (MO1 e MO2, Table 2) are representative of the wet period, with the aquifer still under the 
influence of the recharge waters (rain), verified by the shallowest water levels observed. Deeper water levels for the Jandaíra aquifer are observed from March to November, probably due to low rainfall (recharge) which occurred from August of the previous year. Therefore, the November sampling events (CHA and MO3, Table 2) are representative of the end of the dry period. It is evident that the seasonal effect can influence variation of the static level of the Jandaíra aquifer, even with delay due to slow percolation through the unsaturated zone.

Table 3: Data for groundwater boreholes and descriptive statistics.

\begin{tabular}{|c|c|c|c|c|c|c|c|c|c|}
\hline \multirow{2}{*}{ Station } & \multirow{2}{*}{$X^{1}$} & \multirow{2}{*}{$\mathbf{Y}^{1}$} & \multirow{2}{*}{$\mathbf{Z}$} & \multirow{2}{*}{ Depth } & \multicolumn{3}{|c|}{ Jandaíra Formation } & \multirow{2}{*}{$\begin{array}{l}\text { Water } \\
\text { level }^{2}\end{array}$} & \multirow{2}{*}{$\begin{array}{c}\text { Piezometric } \\
\text { level }^{2}\end{array}$} \\
\hline & & & & & Top & Base & Tickness & & \\
\hline 9-IRR-01-CE & 9475551.74 & 662053.60 & 72.775 & 80.5 & 10 & 79 & 69 & 61.28 & 11.50 \\
\hline 9-IRR-02-CE & 9475299.42 & 662031.30 & 71.691 & 81 & 15 & 79 & 64 & 58.76 & 12.93 \\
\hline 9-IRR-03-CE & 9475303.16 & 662276.30 & 75.282 & 84 & 12 & 82 & 70 & 63.67 & 11.61 \\
\hline 9-IRR-04-CE & 9475166.93 & 662159.20 & 75.258 & 84 & 20 & 82 & 62 & 61.79 & 13.47 \\
\hline 9-IRR-05-CE & 9475406.25 & 662060.00 & 72.687 & 81 & 10 & 79 & 69 & 62.35 & 10.34 \\
\hline 9-IRR-06-CE & 9475074.04 & 662170.00 & 74.205 & 82 & 18 & 82 & 64 & 63.67 & 10.54 \\
\hline 9-IRR-07-CE & 9475443.26 & 662141.80 & 74.735 & 84 & 12 & 82 & 70 & 66.62 & 8.11 \\
\hline 9-IRR-08-CE & 9475281.57 & 662175.40 & 74.439 & 82 & 12 & 80 & 68 & 64.70 & 9.74 \\
\hline 9-IRR-09-CE & 9475410.03 & 662201.00 & 75.401 & 85 & 13 & 84 & 71 & 64.03 & 11.37 \\
\hline 9-IRR-10-CE & 9475235.10 & 662081.60 & 73.59 & 80 & 16 & 80 & 64 & 65.40 & 7.53 \\
\hline 9-IRR-11-CE & 9475376.99 & 661975.00 & 71.272 & 80 & 9 & 78 & 69 & 62.98 & 8.29 \\
\hline 9-IRR-12-CE & 9475472.04 & 662019.00 & 73.351 & 82 & 12 & 81 & 69 & 61.25 & 12.10 \\
\hline Pz1 & 9475255.63 & 662072.10 & 72.97 & 80 & 15 & 79 & 64 & 62.20 & 10.77 \\
\hline Pz2 & 9475317.48 & 662261.90 & 75.197 & 83 & 19 & 83 & 64 & 63.48 & 11.72 \\
\hline Pz4 & 9475492.80 & 662064.30 & 73.306 & 66 & 9 & NI & NI & 61.19 & 12.12 \\
\hline Pz5 & 9475094.64 & 662161.80 & 74.824 & 80 & 28 & 81 & 53 & 63.97 & 10.86 \\
\hline Pz6 & 9475319.19 & 661974.90 & 71.581 & 80 & 9 & 75 & 66 & 60.86 & 10.73 \\
\hline Pz7 & 9475383.49 & 662197.40 & 74.594 & 80 & 11 & 80 & 69 & 64.07 & 10.52 \\
\hline Pz8 & 9475179.65 & 662296.20 & 76.435 & 86 & 15 & 86 & 71 & 66.01 & 10.43 \\
\hline Pz9 & 9475529.37 & 662300.60 & 75.827 & 85 & 18 & 85 & 67 & 65.65 & 10.18 \\
\hline Pz10 & 9475176.23 & 662019.40 & 74.323 & 83 & 11 & 83 & 72 & 63.57 & 10.75 \\
\hline \multicolumn{10}{|c|}{ Descriptive statistics } \\
\hline \multicolumn{3}{|c|}{ Minimum } & 71.27 & 66.00 & 9.00 & 75.00 & 53.00 & 58.76 & 7.53 \\
\hline \multicolumn{3}{|l|}{ Maximum } & 76.44 & 86.00 & 28.00 & 86.00 & 72.00 & 66.62 & 13.47 \\
\hline \multicolumn{3}{|l|}{ Mean } & 73.99 & 81.36 & 14.00 & 81.00 & 66.75 & 63.21 & 10.74 \\
\hline \multicolumn{3}{|c|}{ Standard deviation } & 1.45 & 4.02 & 4.68 & 2.58 & 4.36 & 1.95 & 1.48 \\
\hline
\end{tabular}

1: WGS 84 Coordinate System $\quad$ 2: August, 2010. NI: Not Intercepted

\subsubsection{PREFERENTIAL FLOW PATH DEVELOPMENT}

The piezometric surface in the sampling events (Figure 5) had an underground flow with areas of higher hydraulic heads of divergent flow (for example, 9-IRR-04-CE) and sectors of lower hydraulic heads with convergent flow (for example, 9-IRR-10-CE). This configuration is the same in all maps, regardless of the seasonal effect on the water level in the wells, and allows confident definition of upstream and downstream wells in the experiment area. According to the equipotential curves, the activities of the experiment can reach wells 9-IRR-05-CE, 9IRR-07-CE, 9- IRR-08-CE, 9-IRR-09-CE, 9IRR-10-CE，9-IRR-11-CE e 9-IRR-12-CE, because the underground flow is moving from the experimental area toward these wells. Conversely, wells 9-IRR-01-CE, 9-IRR-02CE, 9-IRR-03-CE, 9-IRR-04-CE and 9-IRR06-CE all are located in high hydraulic head regions, therefore upstream of the experiment area in relation to the underground flow. 

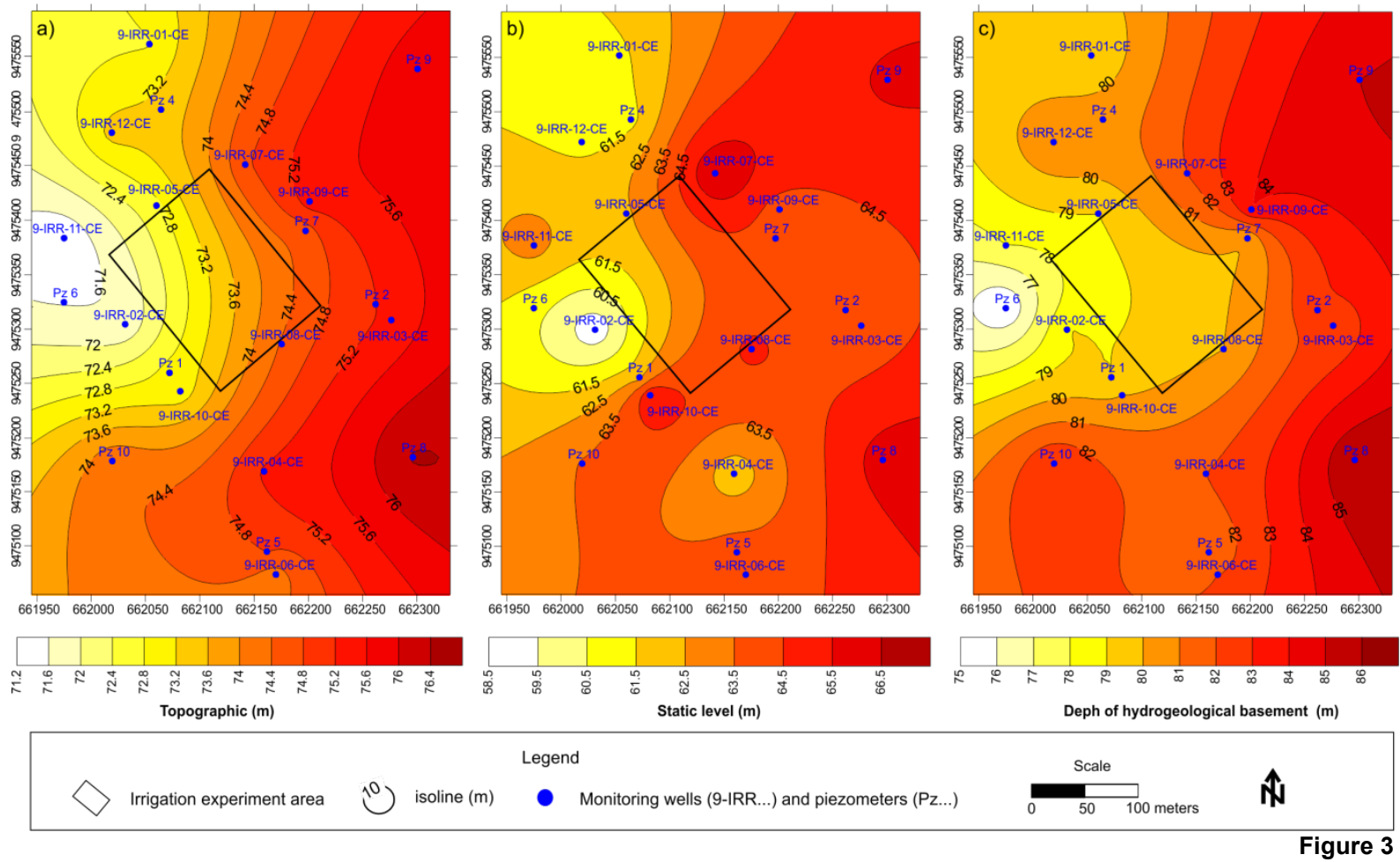

a) Topographic map. b) Static water level map (measurement on 08/21/2010). c) Top of the Açu Formation 251 (hydrogeological basement).

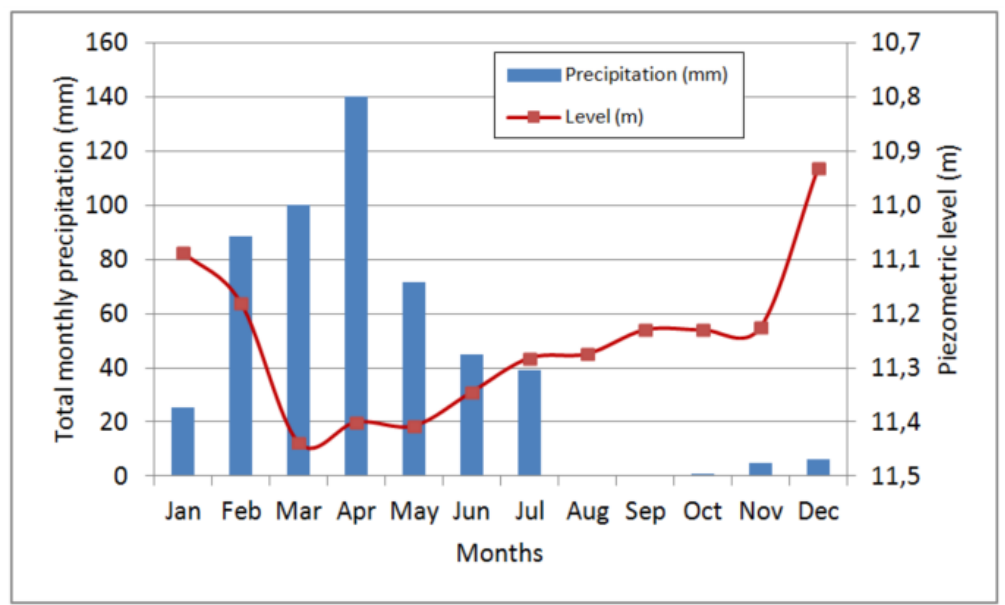

Figure 4

Average monthly rainfall (August, 2010 to January 2015) and average piezometric level (relative to the sea level) in the 12 wells, in the same period.

\subsection{HYDROGEOCHEMICAL}

\subsubsection{CHEMICAL CHARACTERISTICS}

For all sampling periods, the Piper diagram (Piper 1944) (Figure 6) shows predominance of sodium chloride waters, followed by calcium sodium-chloride waters. Samples in the Gibbs diagram (Gibbs 1970) (Figure 7) show that the hydrochemical evolution mechanisms of these waters are evaporation and crystallization. This reflects the semi-arid to semi-humid climate, with low rainfall and high solar radiation, where water evaporation and concentration of salts in soil and unsaturated zone occurs, which are driven to the saturated zone during recharging. 

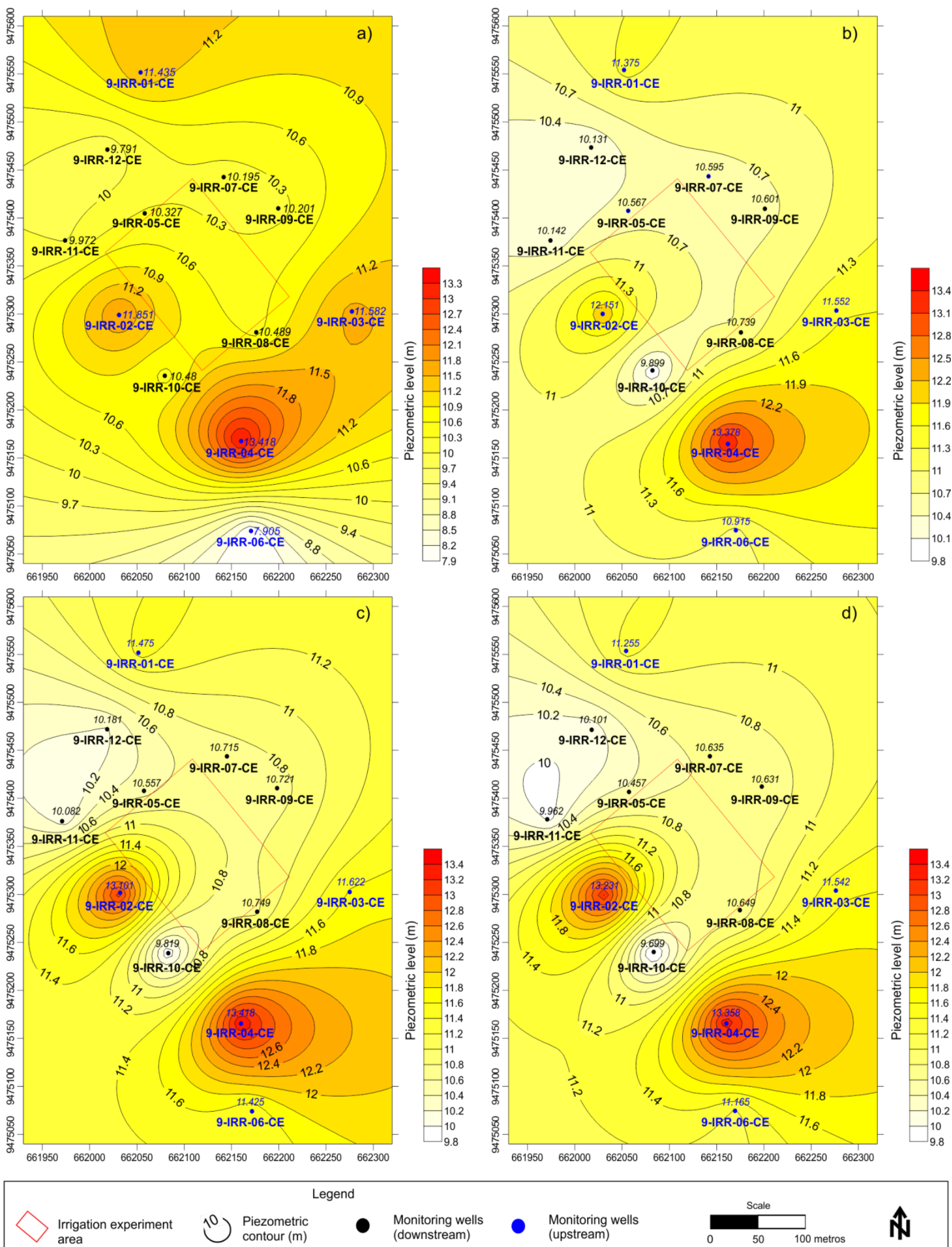

Monitoring wells
(upstream)

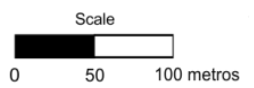

N

Figure 5

Piezometric contours during sampling. A) Characterization. B) Monitoring 1. C) Monitoring 2. D) Monitoring 3. 


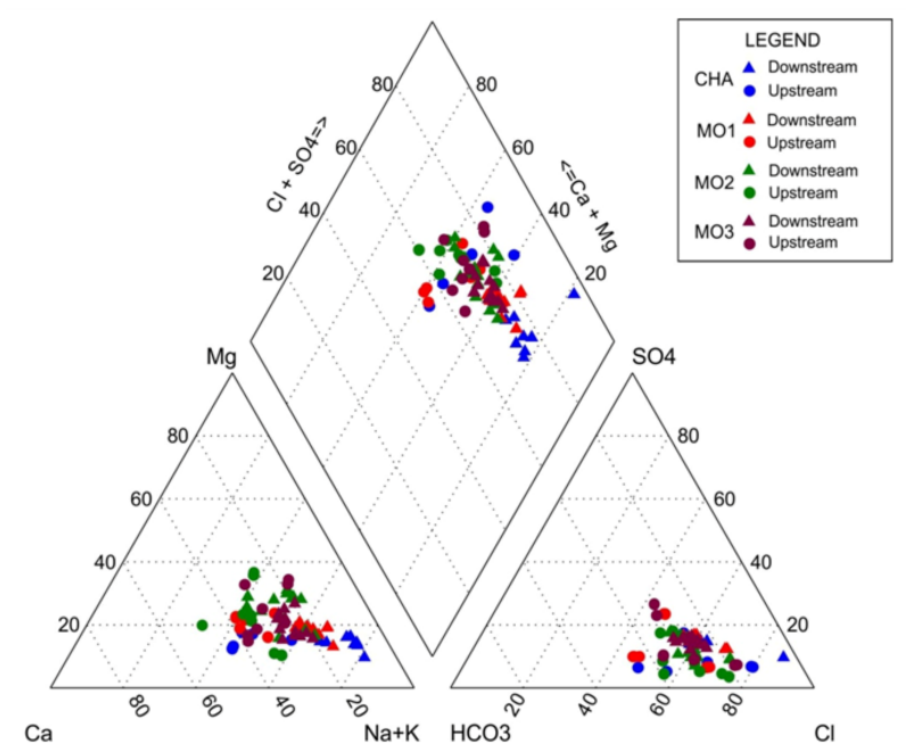

Figure 6

Piper diagram of analyzed groundwater samples.

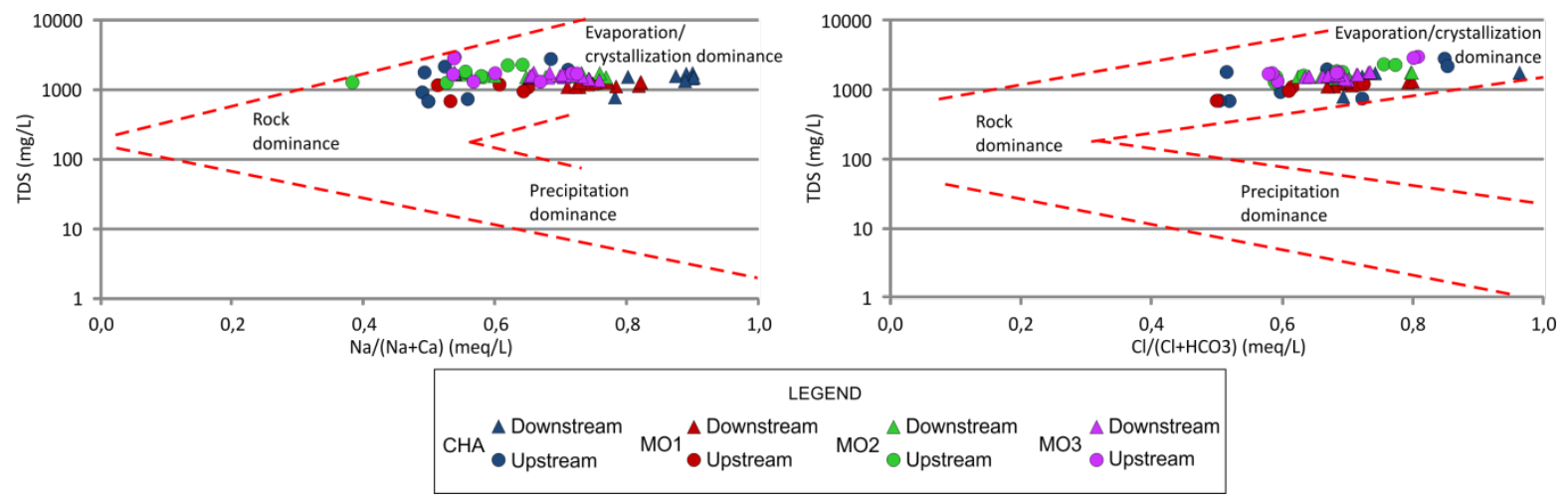

Figure 7 Gibbs diagram for evaluation of mechanisms controlling groundwater signature in Jandaíra aquifer.

\subsubsection{COMPARING PRE AND POST EXPERIMENT WATER COMPOSITION}

\subsubsection{PHYSICAL-CHEMICAL RESULTS AND CHEMICAL ELEMENTS}

The evaluations were performed considering two groups: (1) upstream wells and (2) downstream wells. Within each group, non-parametric statistical inference using Friedman test (Hollander and Wolfe 1999) were applied to verify if there is one or more sampling stages whose results, for a given parameter, differ statistically from the others. The non parametric test was applied because the data do not fit the Normal distribution. It is observed that, for the great majority of the variables involved, at least one sampling event is different from the others (rejects H0) (Table 4). This outcome is discussed below, for each parameter, using descriptive statistics (Tables 5 and 6), scatter plots and box plots (Figures 8 to 10). Table 7 presents the synthesis of the analytical results of downstream wells in relation to the experimental area, grouped in three different scenarios, according to their behavior in MO1, MO2 and MO3 stages in relation to CHA stage. 
Table 4 - Friedman statistical test summary (significant at $\mathrm{p} \leq 0.05$ ) for comparison between the four sampling events 316 (CHA, MO1, MO2 and MO3), in each well group (upstream and downstream); Ho: Results of the four sampling stages 317 are not different from each other; $\mathrm{H} 1$ : At least one sampling stage differs from the others.

\begin{tabular}{|c|c|c|}
\hline Parameter & Among upstream wells & Among downstream wells \\
\hline $\mathrm{EC}$ & Accept $\mathrm{H}_{0}$ & Reject $\mathrm{H}_{0}$ \\
\hline $\mathrm{pH}$ & Accept $\mathrm{H}_{0}$ & Accept $\mathrm{H}_{0}$ \\
\hline $\mathrm{Ca}^{2+}$ & Accept $\mathrm{H}_{0}$ & Reject $\mathrm{H}_{0}$ \\
\hline $\mathrm{Na}^{+}$ & Accept $\mathrm{H}_{0}$ & Reject $\mathrm{H}_{0}$ \\
\hline $\mathrm{Mg}^{2+}$ & Reject $\mathrm{H}_{0}$ & Reject $\mathrm{H}_{0}$ \\
\hline $\mathrm{K}^{+}$ & Accept $\mathrm{H}_{0}$ & Reject $\mathrm{H}_{0}$ \\
\hline Hardness & Accept $\mathrm{H}_{0}$ & Reject $\mathrm{H}_{0}$ \\
\hline $\mathrm{Cl}^{-}$ & Accept $\mathrm{H}_{0}$ & Accept $\mathrm{H}_{0}$ \\
\hline $\mathrm{SO}_{4}^{2-}$ & Reject $\mathrm{H}_{0}$ & Accept $\mathrm{H}_{0}$ \\
\hline $\mathrm{HCO}_{3}^{-}$ & Reject $\mathrm{H}_{0}$ & Reject $\mathrm{H}_{0}$ \\
\hline $\mathrm{F}^{-}$ & Reject $\mathrm{H}_{0}$ & Reject $\mathrm{H}_{0}$ \\
\hline $\mathrm{NO}_{3}^{-}$ & Accept $\mathrm{H}_{0}$ & Reject $\mathrm{H}_{0}$ \\
\hline As & Reject $\mathrm{H}_{0}$ & Reject $\mathrm{H}_{0}$ \\
\hline $\mathrm{B}$ & Reject $\mathrm{H}_{0}$ & Reject $\mathrm{H}_{0}$ \\
\hline $\mathrm{Ba}$ & Accept $\mathrm{H}_{0}$ & Reject $\mathrm{H}_{0}$ \\
\hline $\mathrm{Fe}$ & Accept $\mathrm{H}_{0}$ & Accept $\mathrm{H}_{0}$ \\
\hline $\mathrm{Li}$ & Accept $\mathrm{H}_{0}$ & Reject $\mathrm{H}_{0}$ \\
\hline $\mathrm{P}$ & Reject $\mathrm{H}_{0}$ & Reject $\mathrm{H}_{0}$ \\
\hline
\end{tabular}

\section{Electrical conductivity}

According to the statistical test for the set of upstream wells, results of the electrical conductivity in the four sampling stages are statistically the same. This similarity can also be evidenced by the mean and median results (Table 5) represented in box plots (Figure 8). In the scatter plots, as well as in this figure, it is observed that all results tend to locate near the line of equal value $(1: 1)$, confirming the lack of significant variations for this parameter as a function of the sampling stage. The same non-parametric statistical test showed that at least one sampling stage is statistically different from the others for the set of

pH

Using Friedman test for $\mathrm{pH}$ measurement, results of upstream and downstream wells in the four sampling stages are statistically similar (Table 4). The variation of this parameter in the group of upstream wells showed results close to neutrality (minimum of 6.9 in CHA stage up to maximum of 7.4 in CHA and MO3 stages), according to Table 5.

\section{Calcium}

The four sampling stages are statistically similar for $\mathrm{Ca}^{2+}$ in the upstream well group, according to the Friedman test (Table 4). From the analysis of the scatter plots of Figure 8, it is verified that $\mathrm{MO} 1$ and $\mathrm{MO} 2$ samples showed a slight increase in the contents of this element, downstream wells (Table 4). Indeed, analyzing the scatter plots (Figure 8), it is observed that results of the MO3 sampling, in relation to CHA, are slightly deviated from the line of equal value where the analytical results of the other sampling stages are positioned. In this case, among all sampling events, the smallest analytical results for this parameter are verified in MO3 (Figure 8). This variation is probably due to natural effects, rather than to some contribution from the irrigation experiment performed, since some influence of the activity would be expressed through increase in this parameter in the monitoring stages.

In the downstream wells (Table 6) the minimum $\mathrm{pH}$ value was 7.1 , in CHA stage. In this same stage, maximum value was 7.7 for the set of wells. Scatter plots and box plots for this parameter are shown in Figure 8, where no trend is observed in the results during the sampling steps.

but stage MO3 shows a reduction, with values close to those obtained in CHA. It is likely that this scenario reflects the climatic component, since MO1 and MO2 sampling events occurred in the wet season of the region, when recharge 


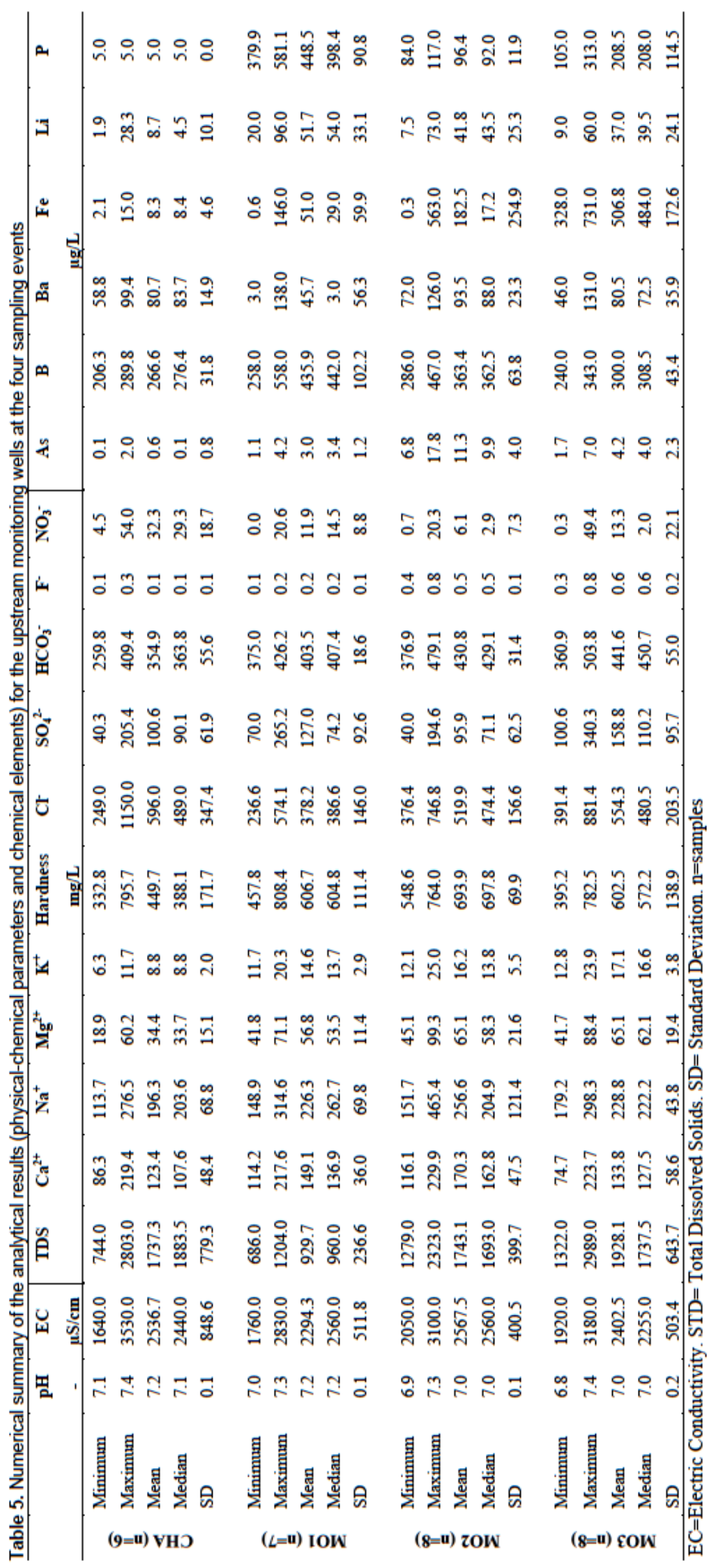




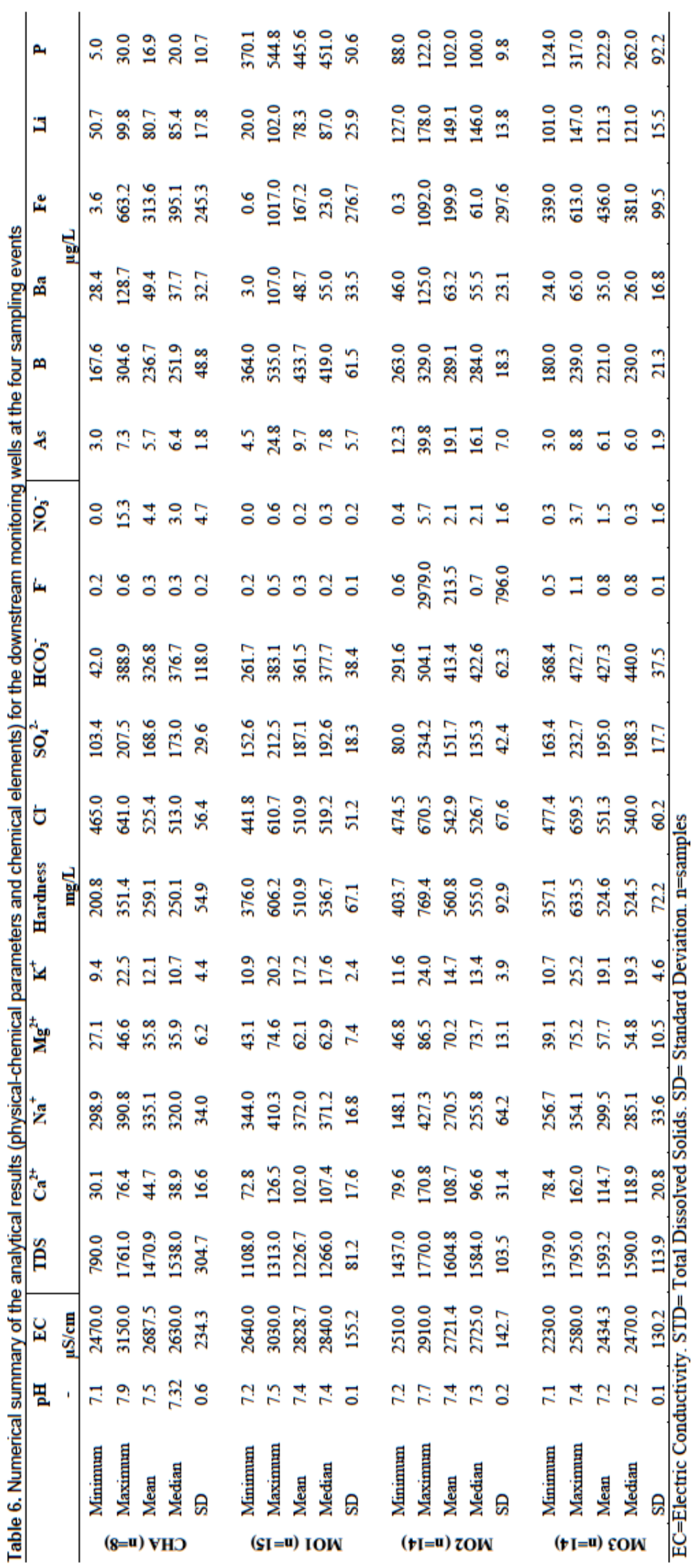




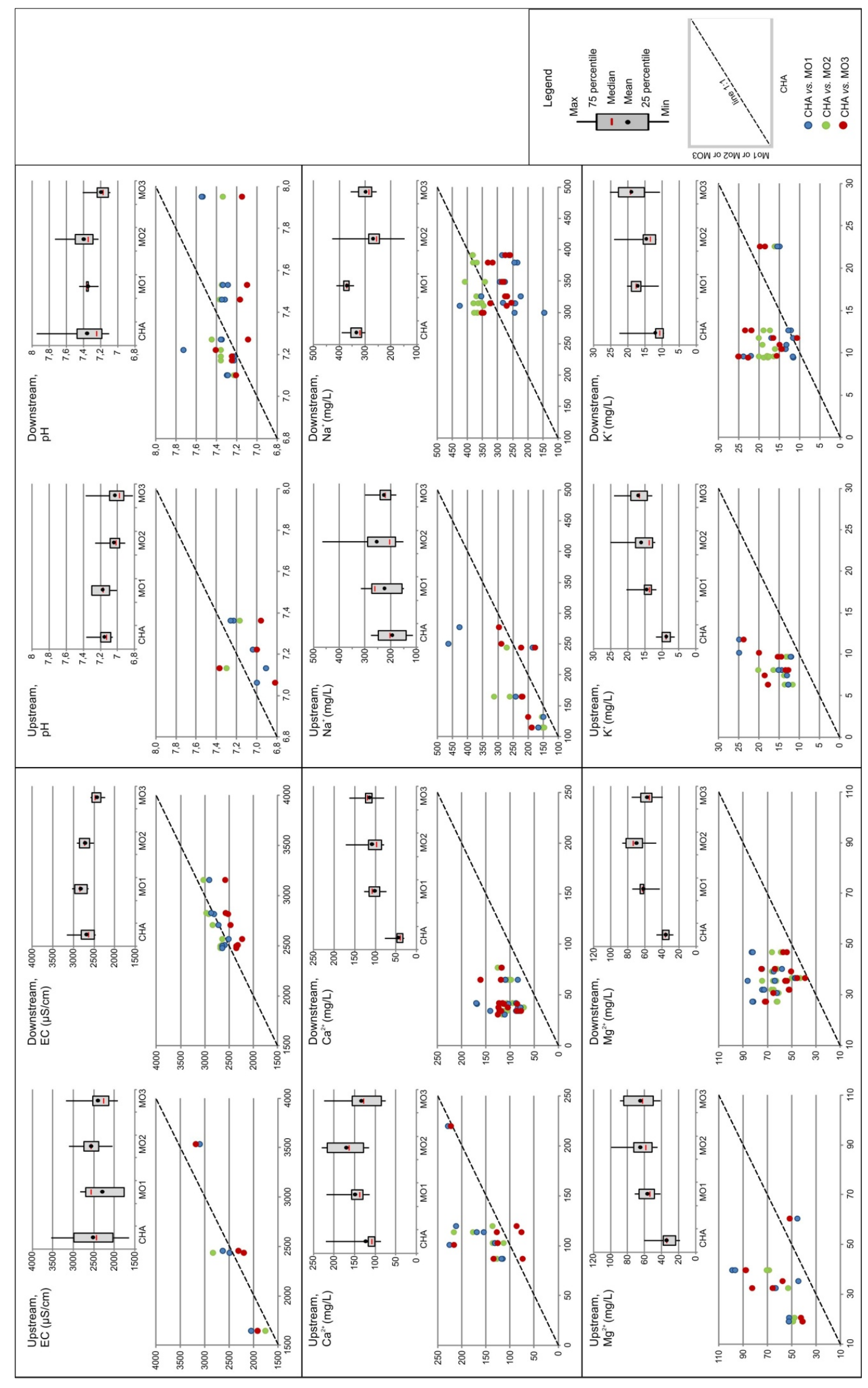

Figure 8 Boxplots and scatterplots for $\mathrm{EC}, \mathrm{pH}, \mathrm{Ca} 2+, \mathrm{Na}+, \mathrm{Mg} 2+$ and $\mathrm{K}+$ in upstream and downstream wells 


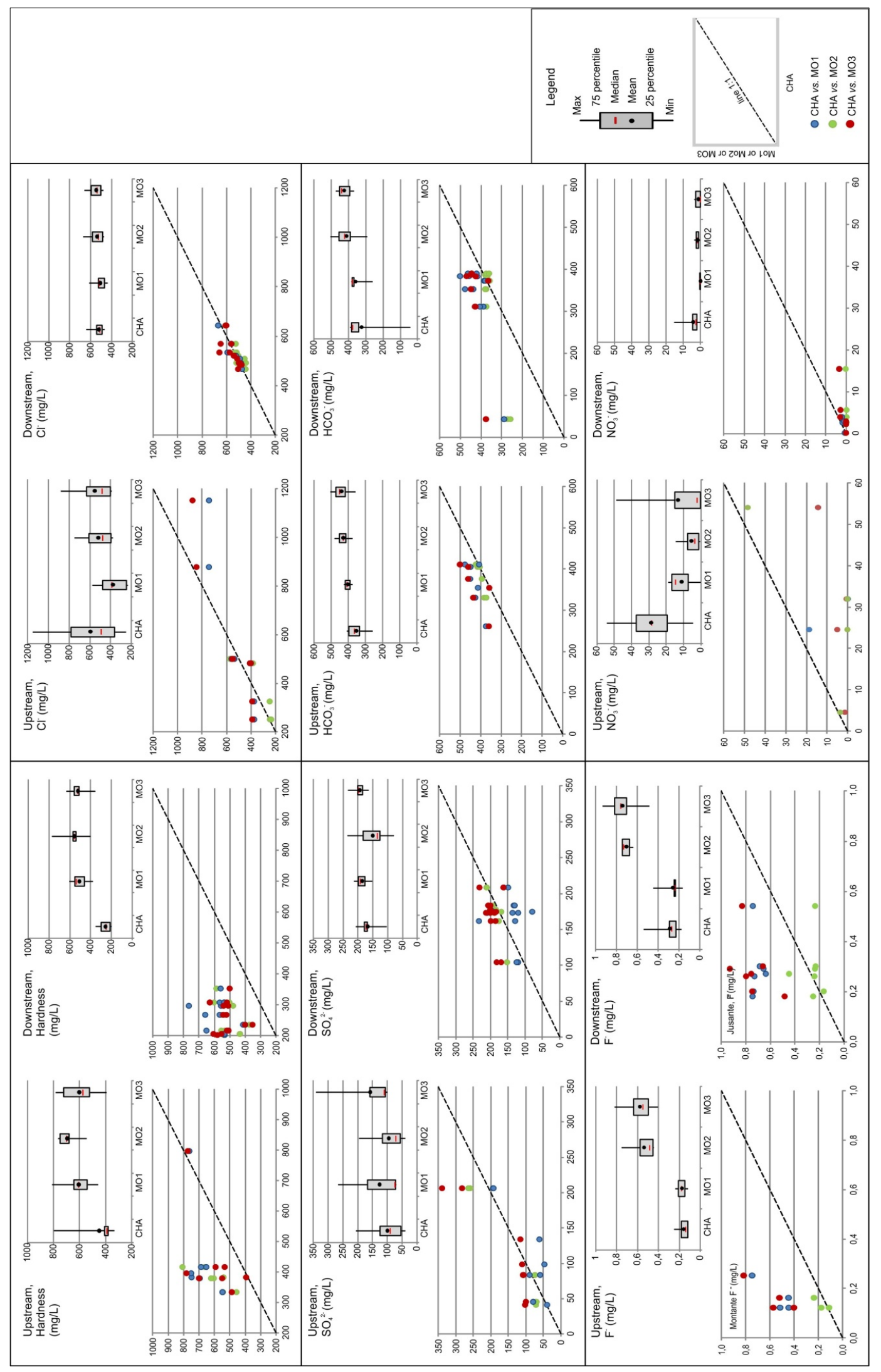

Figure 9 Boxplots and scatterplots for hardness, $\mathrm{Cl}-, \mathrm{SO} 42-, \mathrm{HCO} 3-, \mathrm{F}-$ and NO3- in upstream and downstream wells 


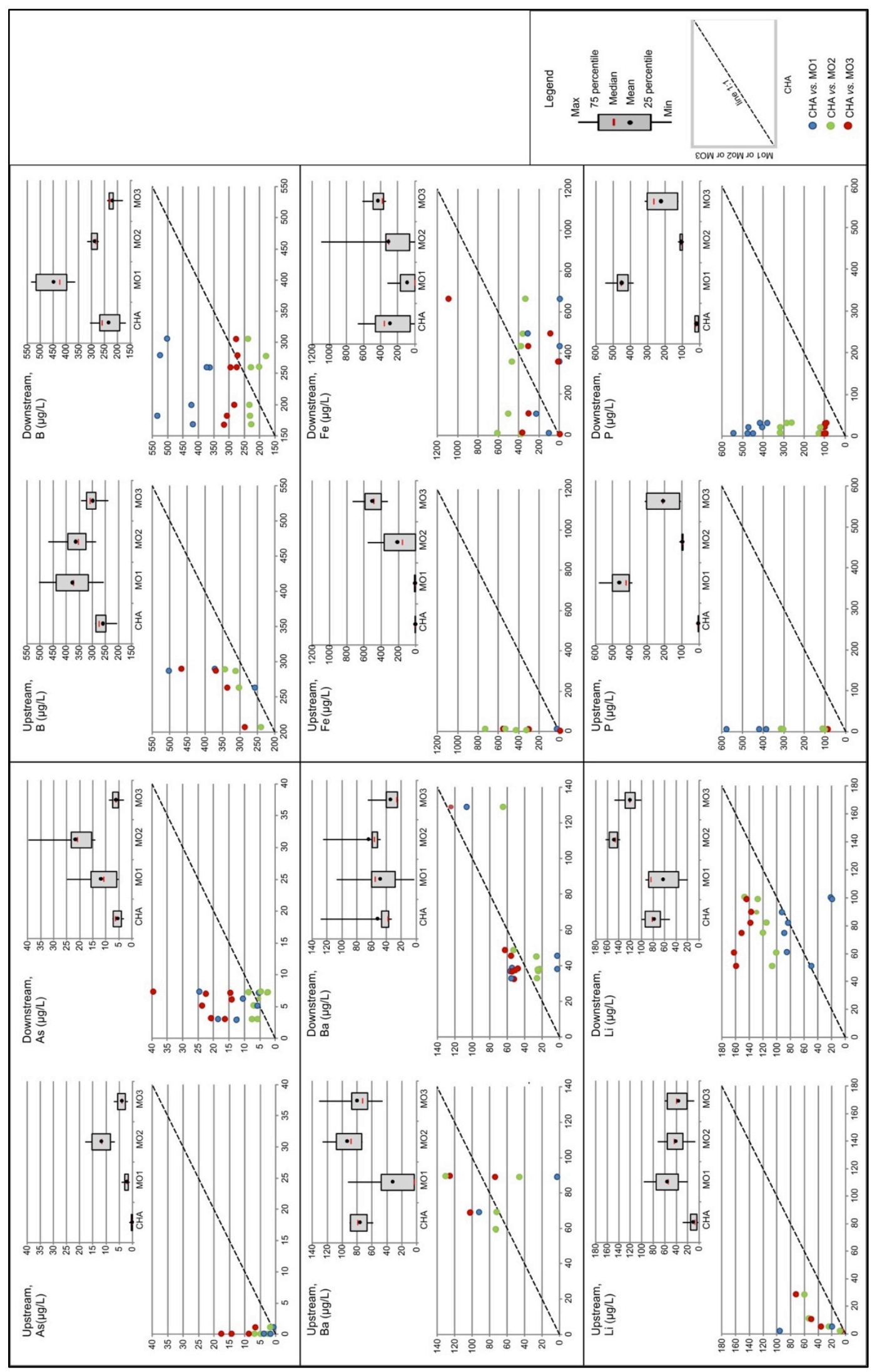

Figure 10

Boxplots and scatterplots for $\mathrm{As}, \mathrm{B}, \mathrm{Ba}, \mathrm{Fe}, \mathrm{Li}$ and $\mathrm{P}$ in upstream and downstream wells 
Table 7: Synthesis of the analytical results (physical-chemical parameters and chemical elements) of downstream wells in the monitoring stages in relation to the CHA stage

\begin{tabular}{|c|c|c|}
\hline Situation & $\begin{array}{c}\text { Trend of downstream wells in the MO1, MO2 and MO3 } \\
\text { stages in relation to the CHA stage }\end{array}$ & Parameters \\
\hline I & Increase of results & $\begin{array}{c}\mathrm{Ca}^{2+}, \mathrm{Mg}^{2+}, \mathrm{K}^{+}, \text {hardness, } \mathrm{HCO}_{3}^{-}, \\
\mathrm{F}^{-}, \mathrm{As}, \mathrm{B}, \mathrm{Li}, \mathrm{P}\end{array}$ \\
\hline II & Decrease in results & ${\mathrm{EC}, \mathrm{Na}^{+}, \mathrm{NO}_{3}^{-}}^{-{ }^{-}}$ \\
\hline III & No trend & $\mathrm{pH}, \mathrm{Cl}^{-}, \mathrm{SO}_{4}^{2-}, \mathrm{Ba}, \mathrm{Fe}$ \\
\hline
\end{tabular}

waters promote dissolution of carbonate constituents present in the aquifer. For the set of downstream wells, the statistical test (Table 4) showed that at least one of the sampling stages differs from the others. Scatter plots and box plots (Figure 8) shows that the three monitoring events resulted on higher analytical results when compared to those from CHA. In the characterization stage, average $\mathrm{Ca}^{2+}$ content was $44.7 \mathrm{mg} / \mathrm{L}$ and median was 38.9 $\mathrm{mg} / \mathrm{L}$ (Table 6). In the monitoring stages, mean

\section{Sodium}

According to the Friedman test for the set of upstream wells, results of $\mathrm{Na}^{+}$parameter in the four sampling events are statistically similar (Table 4). The scatter plots of Figure 8 show that part of the results is distributed near the line of equal value $(1: 1)$ and in the box plots the mean and median of the data are close at all sampling stages. Analyzing nonparametric test for $\mathrm{Na}^{+}$in the downstream wells, it is verified that at least one sampling

\section{Magnesium}

Friedman's non-parametric statistical test shows that for $\mathrm{Mg}^{2+}$ at least one sampling stage is different from the other stages for both groups (upstream and downstream) (Table 4). In fact, the analysis of the scatter plots of Figure 8 shows that the vast majority of $\mathrm{Mg}^{2+}$ results are higher in the monitoring steps when compared to CHA, and this occurs for both upstream and downstream wells. The box plots in the same figure confirm this scenario and also allow to verify a slight decrease of the contents of this element in the last sampling

\section{Potassium}

According to the Friedman test for the set of upstream wells, $\mathrm{K}^{+}$analytical results of the four sampling steps exhibit statistically similar concentrations (Table 4). A slight increase in the monitoring steps relative to CHA can be and median obtained were 102.0 and 107.4 $\mathrm{mg} / \mathrm{L}$ (MO1); 108.7 and $96.6 \mathrm{mg} / \mathrm{L}$ (MO2); 114.7 and $118.9 \mathrm{mg} / \mathrm{L}$ (MO3), respectively, hence much higher than CHA. In this case, in addition to the climatic effect as discussed for upstream wells, it is probable that natural concentrations of this element may have been enhanced as part of the agricultural procedures (correctives and fertilizers) and then reached the aquifer environment during recharge events.

stage is statistically different from the others (Table 4). For the box plots of Figure 8 it is verified that the highest analytical values are in events CHA and MO1. In MO2 and MO3 stages it is observed a reduction in $\mathrm{Na}^{+}$levels in these wells, with lower values than those obtained in the CHA. Thus, for this parameter the influence of the experiment in the waters of the Jandaíra aquifer is not observed.

stage (MO3), when compared to the other monitoring sampling events. Considering that this pattern of data distribution occurs in both groups of wells, it cannot be said that the experiment promotes significant $\mathrm{Mg}^{2+}$ contribution to the waters of the Jandaíra aquifer. In addition, higher $\mathrm{Mg}^{2+}$ levels observed in the MO1 and MO2 stages may reflect the dissolution of the aquifer lithology, considering the effect of these sampling events during the wet season.

observed in box plots and scatter plots of Figure 8 for this set of wells. For the set of downstream wells, the nonparametric test showed that at least one sampling step has $\mathrm{K}^{+}$ results statistically different from the others 
(Table 4). This is probably due to the large amplitude in the results as can be seen in box plots of Figure 8. Regarding the influence of the experiment on the waters of the Jandaíra aquifer, this effect cannot be confirmed because, for both sets of wells (upstream and

\section{Hardness}

Friedman's nonparametric statistical test for hardness showed that in the four sampling stages the analytical data are not different from each other for the set of upstream wells (Table 4). The box plots (Figure 9) show similar amplitudes between the four sampling stages, although in the monitoring stages, means and medians were higher when compared to CHA.

For the downstream wells, the statistical test showed that at least one of the sampling stages differs from the others. Analysis of scatter plots and box plots (Figure 9) shows that the three monitoring stages presented

\section{Chloride}

According to Friedman test for the upstream and downstream wells, results of the $\mathrm{Cl}^{-}$parameter show statistically similar concentrations in the four sampling stages

\section{Sulfate}

The Friedman non-parametric statistical test (Table 4) applied to upstream wells showed that at least one of the sampling stages differs from the others for this parameter. In the downstream wells the test did not indicate any difference between the four sampling steps. The box plots show a large amplitude of

\section{Bicarbonate}

Friedman's nonparametric statistical test showed that, for $\mathrm{HCO}_{3}{ }^{-}$in both well sets (upstream and downstream), at least one sampling stage presents different analytical results from those of the other stages (Table 4). In fact, analytical results presented in scatter plots (Figure 9) show that, for the vast majority of data, the highest values are in the

\section{Fluoride}

Friedman's non-parametric statistical test showed that for $\mathrm{F}^{-}$at least one sampling stage presents analytical results different from the others, for both sets of wells (upstream and downstream), and not only for the downstream wells, a slight increase in $\mathrm{K}^{+}$concentrations is observed in the monitoring stages. However, part of the increase in content may be from fertilizers added to the soil.

higher analytical results when compared to the CHA sampling. Considering that this pattern of data distribution occurs in both groups of wells, it is not ruled out that part of the increase in the water hardness in the downstream wells in the monitoring stages comes from correctives and fertilizers added to soil during the agricultural experiment. Hardness is a parameter that is related to $\mathrm{Ca}^{2+}$ and $\mathrm{Mg}^{2+}$ content of the waters, and this scenario was individually considered above for both of these parameters.

(Table 4). In fact, scatter plots of Figure 9 show that, for both sets of wells, the analytical data tend to concentrate near the line of equal value.

results between the four sampling events for the upstream wells, which does not occur significantly in the downstream wells (Figure 9). Thus, for $\mathrm{SO}_{4}{ }^{2-}$ the influence of the experiment in the waters of the Jandaíra aquifer is not observed.

monitoring steps. As this pattern occurs in both well sets, it cannot be said that there has been a change in bicarbonate due to irrigation experiment. Also, it can be seen from box plots of the same figure that the effect of this variations in the results are minimal, as means and medians of the data are located very close to each other (Tables 6 and 7). downstream) (Table 4). Box plots of Figure 9 shows that events $\mathrm{CHA}$ and MO1 present similar and lower analytical results when compared to subsequent events $\mathrm{MO} 2$ and 
MO3. This pattern is the same for both groups of wells. It should be emphasized that in all

\section{Nitrate}

The Friedman test does not recognize a difference in the four sampling stages in upstream wells (Table 4) for parameter $\mathrm{NO}_{3}{ }^{-}$. For the set of downstream wells, the test showed that at least one sampling stage is

\section{Other Elements}

For the elements $\mathrm{As}, \mathrm{B}, \mathrm{Ba}, \mathrm{Li}$ and $\mathrm{P}$ in the set of downstream wells, the Friedman test indicates that at least one sampling step is statistically different from the others (Table 4). For $\mathrm{Fe}$ in this same group of wells, the test does not recognize a difference among the four sampling stages. In box plots and scatter plots of Figure 10, it is showed that for the great majority of results, upstream and downstream

\subsubsection{ORGANIC PARAMETERS}

Table 8 shows organic substances and their respective contents detected in each sampling stages. At CHA, 10 samples showed naphthalene, 02 pyrene, 02 fluoranthene and 1 benzene. In MO1 and MO3, no hydrocarbons of any of the analyzed species were detected (n-alkanes, aromatic hydrocarbons, BTEX and PAHs, dibenzothiophene and phenols). In MO2, 06 samples had n-alkanes (C11 detected in 01 sample, $\mathrm{C} 12$ detected in 01 sample, $\mathrm{C} 14$ detected in 02 samples and $\mathrm{C} 40$ detected in 02 samples). These compounds are in the wells 9IRR-01-CE, 9-IRR-03-CE and 9-IRR-09-CE. The first two are upstream wells and the third is a downstream well. In all situations, the levels detected are low and sparse and do not register any signature of anthropogenic contamination, including that of the irrigation cases $\mathrm{F}^{-}$levels are low and not related to the irrigation activities performed.

statistically different from the others. In scatter plots and box plots of Figure 9, it can be seen that higher $\mathrm{NO}_{3}{ }^{-}$results in downstream wells occur in the CHA stage, therefore not related to the irrigation experiment.

wells sets have the same behaviour. The lowest values are obtained in stage CHA and higher concentrations are seen in MO1, MO2 and, to a lesser extent, in MO3. Therefore, it is not clear the influence of the experiment in the evaluated waters. However due to the same scenario evidenced in groups of upstream wells it is probable that this variation is due to natural factors.

experiment. Sources of hydrocarbons present in the samples are therefore ascribed to natural processes or are related to diffuse regional and global inputs. In other words, there is no record of contamination by petroleum substances that may possibly have been introduced into the groundwater during the agricultural experiment. For the aliphatic fraction, RH (Resolved Hydrocarbons), UCM (Unresolved Complex Mixture) and TH (Total Hydrocarbons) were detected in samples of CHA and MO1 but none of them were detected in MO2 and MO3 (Table 9). The low and sparse levels detected reinforce that there was no addition of organic substances to the groundwater that could be related to the irrigation experiment.

Table 8 - Distribution of aromatic and individual n-alkanes with concentration equal to or greater than the QL; all results expressed in $\mu \mathrm{g} / \mathrm{L}$

\begin{tabular}{|c|c|c|c|c|c|c|c|c|}
\hline \multirow{2}{*}{\multicolumn{2}{|c|}{ Parameter/Sampling }} & \multicolumn{3}{|c|}{ Upstream } & \multicolumn{4}{|c|}{ Downstream } \\
\hline & & ...01-CE & $\ldots 02-\mathrm{CE}$ & $\ldots 03-\mathrm{CE}$ & ...08-CE & ...09-CE & $\ldots 10-\mathrm{CE}$ & $\ldots 12-\mathrm{CE}$ \\
\hline Naphthalene & $\mathrm{CHA}$ & 0.01 & - & - & 0.51 & 0.27 & 0.08 & 0.11 \\
\hline Pyrene & CHA & & 0.93 & & - & - & - & 0.09 \\
\hline Fluoranthene & CHA & - & - & - & - & - & - & 0.12 \\
\hline Benzene & CHA & - & - & - & - & - & 2.73 & - \\
\hline $\mathrm{C} 11$ & $\mathrm{MO} 2$ & - & - & 1.09 & - & - & - & - \\
\hline $\mathrm{C} 12$ & MO2 & - & - & 1.14 & - & - & - & - \\
\hline $\mathrm{C} 14$ & $\mathrm{MO} 2$ & 1.21 & & 1.22 & - & 1.24 & - & - \\
\hline $\mathrm{C} 40$ & $\mathrm{MO} 2$ & 1.36 & - & - & - & - & - & - \\
\hline
\end{tabular}


Table 9 - Distribution of organic compounds (RH, UCM, TH) with concentration equal to or greater than the QL; all results expressed in $\mu \mathrm{g} / \mathrm{L}$.

\begin{tabular}{|c|c|c|c|c|c|c|}
\hline & & Samples $\geq$ LQ & Minimum & Maximum & Mean & Median \\
\hline \multirow{3}{*}{ CHA } & $\mathrm{RH}$ & 0 & $<1.25$ & $<1.25$ & $<1.25$ & $<1.25$ \\
\hline & UCM & 1 & $<100$ & 360 & 114.4 & $<100$ \\
\hline & $\mathrm{TH}$ & 5 & $<0.1$ & 0.75 & 0.18 & $<0.1$ \\
\hline \multirow{3}{*}{ MO1 } & RH & 22 & 8.3 & 17.9 & 13.14 & 13.1 \\
\hline & UCM & 0 & $<100$ & $<100$ & $<100$ & $<100$ \\
\hline & $\mathrm{TH}$ & 22 & 8.3 & 17.9 & 13.14 & 13.1 \\
\hline \multirow{3}{*}{$\mathrm{MO} 2$} & $\mathrm{RH}$ & 0 & $<1.25$ & $<1.25$ & $<1.25$ & $<1.25$ \\
\hline & UCM & 0 & $<100$ & $<100$ & $<100$ & $<100$ \\
\hline & $\mathrm{TH}$ & 0 & $<0.1$ & $<0.1$ & $<0.1$ & $<0.1$ \\
\hline \multirow{3}{*}{ MO3 } & $\mathrm{RH}$ & 0 & $<1.25$ & $<1.25$ & $<1.25$ & $<1.25$ \\
\hline & UCM & 0 & $<100$ & $<100$ & $<100$ & $<100$ \\
\hline & $\mathrm{TH}$ & 0 & $<0.1$ & $<0.1$ & $<0.1$ & $<0.1$ \\
\hline
\end{tabular}

\section{CONCLUSIONS AND RECOMMENDATIONS}

The Jandaíra aquifer in the study area is covered by siliciclastic sediments, with an average thickness of about 14 meters, representing a rainwater transfer unit (recharge) for storage in the karst conduits / channels / cavities of the Jandaíra Formation. Hydrogeological basement of the Jandaíra aquifer is shales and argillites of the Açu Formation, whose top is 81 meters deep. Waters in the Jandaíra aquifer are sodiumchloride type, followed by calcium sodiumchloride type.

The water-level monitoring (from 2010 to $2015)$ in the 12 wells of the study allowed definition of a preferential direction for the groundwater flow in the Jandaíra aquifer. In general, configuration of the piezometric surface is irregular, with regions of higher hydraulic head (divergent flow) and regions of lower hydraulic head (convergent flow), in accordance to the karstic nature of the Jandaíra aquifer. Regardless of the climatic period, the piezometric surface displays the same configuration, although for most wells shallow water levels are recorded in the rainy season and deep water levels are seen in the dry season. This configuration allowed definition of the monitoring wells located upstream and downstream of the PW irrigation experiment area in relation to underground flow.

Sampling events were carried out in four periods from November 2010 to November 2014: Characterization and Monitoring 3 in the dry period and Monitoring 1 and 2 in the wet period. The Jandaíra aquifer waters showed hydrochemical changes throughout the four sampling periods, indicated that climate conditions are the main reason behind these changes.

Most of the parameters have a tendency to increase their results in one of the monitoring stages in relation to Characterization. This is the case for $\mathrm{Ca}^{2+}, \mathrm{Mg}^{2+}, \mathrm{K}^{+}$, hardness, $\mathrm{HCO}_{3}$, $\mathrm{F}^{-}, \mathrm{As}, \mathrm{B}, \mathrm{Li}$ and $\mathrm{P}$. However, this pattern does not occur only in the downstream wells of the experiment area in relation to underground flow. Thus, for these same parameters elevation in their concentrations are also observed in the upstream wells of the experiment. This scenario leads to the conclusion that the main component responsible for hydrochemical variations is essentially due to the influence of seasonal climatic effects. It is observed that some of the higher analytical results occur in Monitoring 1 and Monitoring 2 stages, under the influence of the wet season, when the recharge waters promote dissolution of carbonate constituents present in the aquifer, increasing its dissolved concentration, as observed mainly for $\mathrm{Ca}^{2+}$, $\mathrm{Mg}^{2+}$ and hardness. It is not ruled out that natural concentrations of these parameters may have undergone elevations due to additions in the soil as part of the agricultural procedures, which in turn ended up reaching the Jandaíra aquifer during recharge. However, high data variability probably occurs dissociated from the experiment, since for some parameters results decrease in the monitoring stages or do not present any tendency. The potential influence of the irrigation experiment on groundwater will first occur through the soil surface, i.e. the soil layer, and potentially reach the aquifer after transit through the unsaturated Geochimica Brasiliensis 33(2): 197 - 220, 2019 
zone. The thickness of the unsaturated zone (60 meters), composed of essentially sandyclayey sediments, provides a very efficient natural means for attenuation of possible contaminants from surface.

For the organic substances analyzed in the groundwater samples, few individual aromatic hydrocarbons were detected in the characterization stages, therefore prior to the experiment. Their concentrations are very low and dispersed, being interpreted as natural or due to diffuse anthropogenic contributions. In

\section{ACKNOWLEDGMENTS}

The authors thank to CENPES (PETROBRAS Research and Development Center) for the financial support of this

\section{REFERENCES}

ABNT. 2007. Associação Brasileira de Normas Técnicas. NBR 15495-1:2007. Poços de monitoramento de águas subterrâneas em aquíferos granulados Parte 1: Projeto e construção. Parte 2: Limpeza e Desenvolvimento. $25 \mathrm{p}$.

ABNT. 2010. Associação Brasileira de Normas Técnicas. NBR 15847:2010. Amostragem de Água Subterrânea em Poços de Monitoramento - Método de Purga. 15p.

ALL Consulting. 2003. Handbook on coal bed methane produced water: management and beneficial use alternatives. Prepared For, Ground Water Protection Research Foundation U.S. Department of Energy National Petroleum Technology Office Bureau of Land Management. Accessed from http:// www.allllc.com/CBM/BU/index.htm

Allen, R.M., \& Robinson, K. 1993. Environmental aspects of produced water disposal. In Proceedings of Middle East oil show (pp. 1-16). Bahrain: Society of Petroleum Engineers. doi:10.2118/25549-MS.

Amini, S., Mowla, D., Golkar, M., \& Esmaeilzadeh, F. 2012. Mathematical modelling of a hydrocyclone for the down-hole oil-water separation (DOWS). Chemical Engineering Research and Design, v. 90, p. 2186-2195.

ANA. 2010. Agência Nacional de Águas. Superintendência de Planejamento de Recursos Hídricos. Avaliação dos Recursos Hídricos Subterrâneos e Proposição de Modelo de Gestão Compartilhada para os Aquíferos da Chapada do Apodi, entre os Estados do Rio Grande do Norte e Ceará. 4 volumes.

Angelim, L.A.A., Nesi, J.R., Torres, H.H.F., Medeiros, V.C., Santos, C.A., Veiga Júnior, J.P., \& Mendes, V.A. 2006. Geologia e Recursos Minerais do Estado do Rio Grande do Norte. Escala 1:500.000. Texto explicativo dos
Monitoring 2, few low concentrations of individual n-alkanes were also detected, reinforcing the erratic (diffuse) aspect of these compounds in the sampled groundwater. $\mathrm{RH}$ (Resolved Hydrocarbons), UCM (Unresolved Complex Mixture) and $\mathrm{TH}$ (Total Hydrocarbons) of the aliphatic fraction were also detected in samples of Characterization and Monitoring 1 stages, but again in very low and dispersed concentrations, being therefore attributed to natural sources or otherwise related to global diffuse origin.

research, carried out at the Geology Department of UFRN.

mapas geológico e de recursos minerais do Estado do Rio Grande do Norte. Recife: CPRM/SEDEC-26 RN/FAPERN, 119p. anexo + 2 mapas. Programa de Geologia do Brasil PGB. Mapeamento geológico. Integrações Geológicas Regionais.

APHA, AWWA, WEF. 2005. Standard Methods for the Examination of Water \& Wastewater. 21 st Edition. Washington, DC.

Araripe, P.T., \& Feijó, F.J. 1994. Bacia Potiguar. Boletim de Geociências da PETROBRAS, v. 8, no.1, p.127-141.

Bertani, R.T., COSTA, I.G., \& MATOS, R.M.D. 1990. Evolução Tectono-Sedimentar, Estilo Estrutural e o Habitat do Petróleo na Bacia Potiguar. In: Raja Gabaglia G.P. \& Milani E.J. (Eds.). Origem e Evolução de Bacias Sedimentares, Petrobras, p.291-310.

Bezerra, F.H.R., MELLO, C.L., \& SUGUIO, K. 2006. A Formação Barreiras: Recentes Avanços e Antigas Questões. Geologia USP Série Científica, 6(2):iii-vi.

Bixio, D., Thoeye, C., Wintgens, T., Ravazzini, A., Miska, V., Muston, M., Chikurel, H., Aharoni, A., Joksimisiv, D., \& Meli, T. 2008. Water reclamation and reuse: implementation and management issues. Desalination 218, 13-23.

Carvalho Júnior, E.R., Baessa, M.P.M., \& Braga Júnior, M.G. 2008. Relações Hidráulicas e Hidroquímicas entre os Aquíferos BarreirasJandaíra e Açu na Região de Fazenda Belém, Estado do Ceará - Brasil. Congresso Brasileiro de Águas Subterrâneas, Natal, RN.

Cavalcante, J. C., Vasconcelos, A. M., Medeiros, M. F., \& Paiva, I. G. 2003. Mapa geológico do Estado do Ceará. Escala 1:500.000. MME/CPRM.

Crisostomo, L.A., Weber, O.B., Miranda, F.R., Aragão, F.A.S., \& Oliveira, M.E.B. 2016. Irrigação com água produzida: efeitos sobre 
características do solo e a produção do girassol. Fortaleza: Embrapa Agroindústria Tropical. In: https://www.embrapa.br/agroindustriatropical/busca-de-publicacoes//publicacao/1053776/irrigacao-com-aguaproduzida-efeitos-sobre-Caracteristicas-do-soloe-a-producao-do-girassol

Cutz-Pool, L.Q., Palacios-Vargas, J.G., CastañoMeneses, G., \& García-Calderón, N. E. 2007. Edaphic collembola from two agroecosystems with contrasting irrigation type in Hidalgo State, Mexico. Applied Soil Ecology, 36(1), 46-52. doi:10. 1016/j.apsoil.2006.11.009.

Diniz, J.A.O., Monteiro, A.B., Silva, R.C., \& De Paula, T.L.F. 2015. Mapa Hidrogeológico do Brasil ao Milionésimo. Recife, PE. Programa de Cartografia Hidrogeológica. Companhia de Pesquisa de Recursos Minerais (CPRM) Serviço Geológico do Brasil.

Fakhru'l-Razi, A., Pendashteh, A., Abdullah, L.C., Biak, D.R., Madaeni, S.S., \& Abidin, Z.Z. 2009. Review of technologies for oil and gas produced water treatment. J. Hazard Mater. 170 (2-3): 530-51.

Ferreira, R.N.C, Weber, O.B., Correia, M.E.F., Benazzi-Ikeda, E.S., Scoriza, R.N., \& Mesquita, A.L.M. 2015. Effects of Wastewater from Oil Exploration on Soil Mesofauna. Bull Environ Contam Toxicol DOI 10.1007/s00128-0151671-9.

FUNCEME. 2015. Fundação Cearense de Meteorologia e Recursos Hídricos. Secretaria dos Recursos Hídricos do Ceará. In: http://www.funceme.br/index.php/areas/23monitoramento/meteorologico/572-postospluviometricos.

Gibbs, R.J. 1970. Mechanisms controlling world water chemistry. Science 17, 1088-1090.

Goldscheider, N., \& Drew, D. 2007. Methods in Karst Hydrogeology: IAH: International Contributions to Hydrogeology. Hardcover. 264 p.

Hollander, M., \& WOLFE, D.A. 1999. Nonparametric Statistical Methods. $2^{\circ}$ Edição. John Wiley \& Sons, New York. 787 p.

Igunnu, E.T., \& Chen, G.Z. 2012. Produced water treatment and technologies. Int. J. Low-Carbon Technol. http://dx.doi.org/10.1093/ijlct/cts049

Johnston, C.R., Vance, G.F., \& Ganjegunte, G.K. 2008. Irrigation with coalbed natural gas coproduced water. Agric Water Manag 95:12431252. doi:10.1016/j.agwat.2008.04.015

Keith, L.H., Crummett, W., Deegan, J., Libby, R.A., Taylor, J.K., Wentler, G. 1983. Principles of environmental analysis. Anal. Chem. 55, 2210-2218. doi:10.1021/ac00264a003

Kresic, N., \& Mikszewsky, A. 2013. Hydrogeological Conceptul Site Models: data analysis and visualization. CRC Press, Boca Raton. 584 p.

Lopes, E.D.O.R., Weber, O.B., Crisostomo, L.A., \& Mattos, E. N. B. 2014. Short-term effects of produced water on microbial activity in semiarid soil. International Journal of Current Microbiology and Applied Sciences, v. 3, p. 395-403.

Matos, R.M.D. 1999. History of the Northeast Brazilian Rift System: Kinematic Implications for the Break-up Between Brazil and West Africa. In: Cameron N.R., Bate R.H. \& Clure V.S. (eds.) The oil and gas Habitats of the South Atlantic. Geological Society, London, Special Publications, 153:55-73.

Melo, J.G., Medeiros, A.B., Vasconcelos, M.B., \& Castro, V.L.L. 2007. Aspectos Hidrogeoquímicos e Classes de Água do Aquífero Cárstico Jandaíra para Irrigação, Baraúna, RN. Revista águas subterrâneas, v.21, n.1, p.9-21.

Melo, M., Schluter, H., Ferreira, J., Magda, R., Júnior, A., \& Aquino, O. 2010. Advanced performance evaluation of a reverse osmosis treatment for oil field produced water aiming reuse. Desalination, v. 250, n. 3, p. 1016-1018.

Miller, G.W. 2006. Integrated concepts in water reuse: managing global water needs. Desalination 187, 65-75.

Mistreta, G. 1984. O Aquífero Jandaíra da Bacia Potiguar. Master's thesis. USP, São Paulo. 226 p.

Morais, F., Melo, J. G. de, Medeiros, J.I. de, Srivastava, N.K., Diniz Filho, J.B., Lopes, V.L., Oliveira, J.A. de, \& Vasconcelos, M.B. 2005. Comportamento das bacias sedimentares da região semi-árida do Nordeste brasileiro. Avaliação do aqüífero Açu na borda sul da bacia Potiguar - Trecho: Upanema-Afonso Bezerra. Recife: CPRM/FINEP, 2005. 82 p.

Motta, A.R.P., Borges, C.P., Kiperstok, A., Esquerre, K.P., Araújo, P.M., \& Branco, L.P.N. 2013. Produced water treatment for oil removal by membrane separation process: review. Eng. Sanit. Ambient.18:1, 15-26.

Moura-Lima, E.N., Sousa, M.O.L., Bezerra, F.H.R., Aquino, M.A., Vieira, M.M., Lima-Filho, F.P., Fonseca, V.P., \& Amaral, R.F. 2010. Sedimentação e deformação tectônica neogênicas e quaternárias no centro da Bacia Potiguar. Geologia USP, Série Científica, v. 10, n. 1, p. $15-28$.

Murray-Gulde, C., Heatley, J.E., \& Karanfil, T. 2003. Performance of a hybrid reverse osmosisconstructed wetland treatment system for brackish oil field produced water. Water Res 37:705-713. 1354(02)00353-6

Pessoa Neto, O.C., Soares, U.M., Silva, J.G.F., Roesner, E.H., Florêncio, C.P., \& Souza, C.A.V. 2007. B. Geoci. Petrobras, Rio de Janeiro, v. 15, n. 2, p. 357-369.

Piper A.M. 1944. A Graphical interpretation of water analysis. Transactions-American Geophysical Union 1944,25, 914-928.

SERHID. 1998a. Secretaria de Recursos Hídricos do Estado do Rio Grande do Norte. Plano Estadual de Recursos Hídricos. Caracterização 
hidroquímica dos aquíferos do Rio Grande do Norte e estudos de vulnerabilidade. Natal/RN. $52 \mathrm{p}$.

SERHID. 1998b. Secretaria de Recursos Hídricos do Estado do Rio Grande do Norte. Plano Estadual de Recursos Hídricos. Caracterização hidrogeológica dos aquíferos do Rio Grande do Norte. Natal/RN. 78 p.

SRH. 2005. Secretaria dos Recursos Hídricos do Ceará. Consolidação da Política e dos Programas de Recursos Hídricos do Estado do Ceará - Atualização do Plano Estadual de Recursos Hídricos - Diagnóstico. 246 p.

Stein, P., \& Melo, J.G. 2006. Potencial Hidrogeológico e Caracterização Hidrogeoquímica do Aqüífero Açu na Borda Sul da Bacia Potiguar no Trecho ApodiUpanema, RN. Revista Brasileira de Recursos Hídricos. Volume 11 n.3: 171-181.

Stein, P., Silva, F.E., Silva, A.I.M., \& Lima, G.L.G. 2014. A Qualidade das Águas Subterrâneas do Município de Baraúnas/RN. Carpe Diem: Revista Cultural e Cientifica do UNIFACEX, Natal-RN, v.12, n.01, 2014.
Stewart, M., \& Arnold, K. 2011. Produced Water Treatment Field Manual. Part 1 - Produced Water Treating Systems, p. 1-134.

Travis, M.J., Weisbrod, N., \& Gross A. 2012. Decentralized wetland-based treatment of oilrich farm wastewater for reuse in an arid environment. Ecol Eng 39:81-89. doi:10.1016/j.ecoleng.2011. 11.008

Veil, J.A., Puder, M.G., Elcock, D., \& Redweik, R.J.J. 2004. A white paper describing produced water from production of crude oil, natural gas, and coal bed methane. Argonne: Argonne National Laboratory. In: $<$ http://www..netl.doe.gov/technologies/oilgas/publications/oil_pubs/prodwaterpaper.pdf $>$.

Xavier, N. P. 2006. Processamento e Interpretação de Dados 2E e 3D de GPR: Aplicações no Imageamento de Feições Kársticas e Estruturas de Dissolução no Campo de Petróleo de Fazenda Belém - CE. Natal, Rio Grande do Norte, Brasil, 2006. Tese (Doutoramento em Geodinâmica e Geofísica). Universidade Federal do Rio Grande do Norte. 